\title{
PIOUS FUNDS ACROSS THE PACIFIC (1668-1823): Charitable Bequests or Credit Source?
}

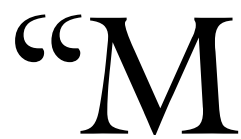

ercy," preached Fray Casimiro Díaz, "is the legitimate daughter of compassion. And the indigent exclaims, the widows, orphans, and destitute women broadcast, even the religious communities acclaim, that mercy is the distinctive virtue of this Holy Board, for your pious gifts reach all of them." The Augustinian friar was addressing the guardians and members of Manila's Hermandad de la Misericordia (Confraternity of Mercy) in a mass that commemorated the anniversary of its foundation in mid September of 1743. At first glance, the occasion would not deserve much attention, another sermon praising the alms-giving labor of a confraternity. Spanish America swelled with similar institutions devoted to administering alms and endowments to sponsor prayers and charity. Yet, the Manila Misericordia was different. Church corporations in the Americas invested donations in low-interest annuities in perpetuity attached to property. Charity donors in Manila had found a better way to maximize pious gifts: by creating legacies to be invested in maritime trade loans at high interests.

The Confraternity of Mercy was the first to use this new type of endowment, but other corporations and individuals followed. Next in importance to the Misericordia were the tertiary orders of the Franciscans, Dominicans, and Augustinians; the Jesuit and Recollect Orders; and the city council. Curiously, Manila citizens began to call the administrators of this new type of pious gifts Obras Pias, the pious works of Manila.

My appreciation to the editors and anonymous readers of The Americas for their advice and critiques. Thank you to John N. Crossley, from Monash University, for his comments on an early version of this paper. This study owes much to the late Professor Lourdes Díaz-Trechuelo, who lent me copies of some important documents and encouraged me to pursue research on this confraternity.

1. Casimiro Díaz, O.S.A., Medida y peso de la Santa Casa de la Misericordia de esta ciudad de Manila: sermón que en la fiesta que hace su V. Hermandad por aniversario de su fundación (Sampaloc, Manila: Convento de Nuestra Señora de Loreto, 1744), 15, http://bdh-rd.bne.es/viewer.vm?id=0000143400\&page=1, accessed July 18, 2016. 
Friar Casimiro Díaz had pointed out that the earnings of these endowments benefited both the needy and ecclesiastic corporations. In the first half of the twentieth century, William L. Schurz highlighted in his pioneering work on the Manila galleon that the Obras Pías became virtual commercial banks for the merchants in the transpacific trade. ${ }^{2}$ More recently, Carmen Yuste, without negating their charitable and religious nature and scope, has taken a new twist on this type of endowment and suggested that the powerful merchant class of Mexico City wholesalers, together with their agents and associates in Manila, was behind this new modality of pious work. The pious investments were a discreet alternative capital source for the Mexican cartel in a market that was banned by law, but which they managed to control in many furtive ways. In that sense, Obras Pías constituted another financial stratagem.

This study probes Yuste's novel and suggestive insight, hoping to determine the intentions behind bequests that apparently conflated devotional and charitable practices with more earthly and materialistic goals. Yuste has suggested that the answers may come after studying the background of the legacies' founders, the reasons for choosing that type of bequest over more traditional ones, and the ways in which administrators used the money of those endowments. ${ }^{3}$ This study does just that, focusing on the Hermandad de la Misericordia, which was not only the first of Manila's Obras Pías but also the one with the largest capital, and the operative model for the others. Documentary sources include the endowments' stipulations, the financial statements of the confraternity and some of its beneficiaries, and the official documents and correspondence of the Misericordia confraternity and civil and ecclesiastical authorities.

This research effort begins with the early practices of pious gift-giving in Manila, and ends in 1823, when commerce between Mexico and the Philippines ended. The investigation owes much to the history of mentalities of Spanish Manila carried out by Spanish historians; institutional approaches of confraternity studies, especially those about Portuguese misericordias; works on church

2. William Lytle Schurz, The Manila Galleon (New York: E. P. Dutton \& Co., Inc., 1939; Manila: Historical Conservation Society, 1985), 141-142; Nicholas P. Cushner, Spain in the Philippines (Quezon City: Ateneo de Manila Press, 1971), 139-152; Lourdes Díaz-Trechuelo, "La Casa de la Misericordia de Manila," in XI Congreso del Instituto Internacional de Historia del Derecho Indiano: Buenos Aires, 4 al 9 de septiembre de 1995: actas y estudios (Buenos Aires: Instituto de Investigaciones de Historia del Derecho, 1997), 4:71-90.

3. Carmen Yuste, "Los comerciantes de la ciudad de México en la negociación transpacífica," in Los negocios y las ganancias de la colonia al México moderno, compiled by Leonor Ludlow and Jorge Silva Riquer (Mexico City: Instituto de Investigaciones de D. José María María Luis Mora, 1993), 217; Yuste, "Obras pías en Manila. La Hermandad de la Santa Misericordia y las correspondencias a riesgo de mar en el tráfico transpacífico en el siglo XVIII," in La Iglesia y sus bienes: de la amortización a la nacionalización, María del Pilar Martínez López-Cano, Elisa Speckman Guerra, and Gisela von Wobeser, eds. (Mexico City: Universidad Autónoma de México, 2004), 200-202; Yuste, Emporios transpacificos. Comerciantes mexicanos en Manila, 1710-1815 (Mexico City: UNAM, 2007), 91-101. 
wealth in Spanish America in Spanish and English; and the studies on transpacific trade during the Spanish period of the Philippines. ${ }^{4}$

\section{The First CENTURy OF SPANISH MANILA}

Manila is situated in a large bay in the island of Luzon, the largest landmass in the Philippine archipelago. This family of many large and small islands has had a long history of trade with Asian neighbors like China and regions in Southeast Asia, and even as far away as India. It is also strategically located at the western end of the Pacific Ocean, which made it the gateway between Spanish America and Asia. Manila became the capital of the Spanish government in the Philippines in 1571, and the Misericordia confraternity accepted the first pious gift that would generate income for charity by means of maritime trade loans in 1668, almost a hundred years later, when Spanish Manila was at its lowest point, not only empty, but desolate. A brief history of the socioeconomic developments of the city in the seventeenth century will help clarify the birth and evolution of pious works.

Just as it had done in Spanish America, but even more intensely due to the slow response it encountered, the Spanish crown sought for more than 50 years to secure settlers for its Asian outpost, a 67-hectare pentagon following the traditional grid design and lying between the sea and the river mouth. The

4. Christopher F. Black, "The Development of Confraternity Studies over the Past Thirty Years," in The Politics of Ritual Kinship: Confraternities and Social Order in Early Modern Italy, Nicholas Terpstra, ed. (Cambridge: Cambridge University Press, 2000), 9-29; Nicholas Terpstra, "De-institutionalizing Confraternity Studies: Fraternalism and Social Capital in Cross-Cultural Contexts," in Early Modern Confraternities in Europe and the Americas: International and Interdisciplinary Perspectives, Christopher Black and Pamela Gravestock, eds. (Aldeshot, UK: Ashgate, 2006), 264-283; Isabel dos Guimarães Sá, Quando o rico se faz pobre: misericórdias, caridades e poder no império portugues 1500-1800 (Lisbon: CNCDP, 1997); Sá, As misericordias portuguesas de D. Mamuel a Pombal (Lisbon: Livros Horizonte, 2001); Antonio García-Abásolo, "The Private Environment of the Spaniards in the Philippines," Philippine Studies, 44 (3rd Quarter 1996): 349-373; García-Abásolo, "Inversiones indianas en Córdoba. Capellanías y patronatos como entidades financieras," in Andalucia y América en el siglo XVI. Actas de las Segundas Jornadas de Andalucía y América, Bibiano Torres Ramírez and José Hernández Palomo, eds. (Seville: Consejo Superior de Investigaciones Científicas, 1983), 1:427-453; Marta María Manchado López, "Poder y vidas licenciosas en Manila en la segunda mitad del siglo XVIII," in Fronteras del mundo hispánico: Filipinas en el contexto de las regiones liminares novohispanas, Marta María Manchado López and Miguel Luque Talaván, eds. (Córdoba, Spain: Universidad de Córdoba, 2011), 135-163; Marta María Manchado López, "Chinos y españoles en Manila a comienzos del siglo XVIII," in Un océano de intercambios: Hispanoasia (1521-1898). Homenaje al Profesor Leoncio Cabrero Fernández, Miguel Luque Talaván and Marta Ma. Manchado López, eds. (Madrid: Dirección General de Relaciones Culturales, Agencia Española de Cooperación Internacional, 2008), 1:141-159; Pilar Martínez López-Cano, Gisela von Wobeser, and Juan Guillermo Muñoz, eds., Cofradías, capellanias y obras pías en la América colonial (Mexico City: UNAM, 1998); Martínez López-Cano, Speckman Guerra and von Wobeser, eds., La Iglesia y sus bienes; Michael P. Costeloe, Church Wealth in Mexico. A Study of the Juzgado de Capellanias' in the Archbishopric of Mexico 1800-1856 (Cambridge: Cambridge University Press, 1967); Arnold J. Bauer, "The Church in the Economy of Spanish America: Censos and Depositos in the Eighteenth and Nineteenth Centuries," Hispanic American Historical Review 63:4 (1983): 707-733; John Frederick Schwaller, Origins of Church Wealth in Mexico. Ecclesiastical Revenues and Church Finances, 1523-1600 (Albuquerque: University of New Mexico Press, 1985); Kathryn Burns, Colonial Habits. Convents and the Spiritual Economy of Cuzco, Peru (Durham and London: Duke University Press, 1999). 
demographic project reached its zenith in 1618 with 2,800 settlers, but it failed at procuring a permanent colony of Spaniards. The long journey, the harsh climate, the distance from the metropole, and the archipelago's scant economic appeal were significant deterrents for colonists. Another weighty obstacle was the fear caused by the Chinese revolts of 1603, 1639, and 1660, and the continuous threat of a Dutch invasion. ${ }^{5}$ Frequent and destructive earthquakes also played a part in the city's mid seventeenth-century decay and demographic downturn. In 1617, Manila boasted more than 200 stone houses and 200 wooden ones, but in 1645 a high-intensity earthquake shook the city mercilessly, toppling or seriously damaging public buildings and houses. Two more earthquakes, in 1658 and 1665, caused more destruction and further dissuaded new settlers. By 1668, there were only 30 vecinos (citizens) or male settlers, a similar number of widows, and more than 100 orphans. Religious and soldiers kept busy about their business and did not earn citizen status. ${ }^{6}$ Moreover, abundant and inexpensive Chinese labor appeared to compensate for the lack of Spanish farmers and artisans.

A small local oligarchy from among the descendants of the early colonists had emerged in the first half of the seventeenth century. Newcomers could join the local gentry through military prowess, marriage, or political deftness. After 1650 , commercial success was the fastest means for social advancement and posts in the city government were highly coveted, for they granted access to the galleon trade. A second upper class, less stable but more politically influential, was created at intervals from the appointees to the colonial government, which included the governor, the magistrates of the audiencia, military officers, and minor colonial officials. These transient bureaucrats also sought to profit from the transpacific trade. Social and economic networks grew around the prominent citizens and the new governors and their entourage.

5. Antonio García-Abásolo, "El poblamiento español de Filipinas (1571-1599)," in España y el Pacífico, Antonio García-Abásolo, ed. (Córdoba: Dirección General de Relaciones Culturales and Asociación Española de Estudios del Pacífico, 1997), 143-155; García-Abásolo, "La expansión mexicana hacia el Pacífico: la primera colonización de Filipinas (1570-1580)," Historia Mexicana, 32:125 (1982): 55-88; García-Abásolo, "Private Environment," 349373; García-Abásolo, "Population Movement in the Spanish Pacific during the 17th Century: Travellers from Spain to the Philippines," Revista Española del Pacifico 19/20 (2006-2007): 133-151; Luis Merino, O.S.A., El cabildo secular: aspectos fundacionales y administrativos (Manila: Intramuros Administration, 1983), 24-54; Inmaculada Alva Rodríguez, Vida municipal en Manila (siglos XVI-XVII) (Córdoba: Universidad de Córdoba, 1997), 26-36; Manchado, "Chinos y españoles," 141-159; Lourdes Díaz-Trechuelo, "Las Filipinas, en su aislamiento, bajo el continuo acoso" in Historia General de España y América (Madrid: Rialp, 1984), IX-2: 129-153.

6. Luis Merino, O.S.A., Arquitectura y urbanismo en el siglo XIX (Manila: Intramuros Administration, 1987), 77 93; Juan Baptista Uriarte, Manifiesto y resumen histórico de la fundación de la venerable Hermandad de la Santa Misericordia de la Ciudad de Manila, Hospital, Casa y Collegio de Niñas, y Iglesia de Santa Ysabel . . (Manila: Collegio y Universidad de Santo Thomas, 1728), fols. 26v-27v, 35; Archbishop Miguel de Poblete to the king, July 16, 1654, Manila, Archivo General de Indias [hereafter AGI], Filipinas, 74, fol. 967r; Provisor y vicario general to archbishop, Manila, January 31, 1739; Archdiocesan Archives of Manila [hereafter AAM], folder 7.A.3. 
The city's influential citizens also included a few secular priests, who kept their eyes on the few available ecclesiastical benefices, and a good number of widows with loading privileges in the galleon. In the 1660s, two boarding facilities, the Colegio de Santa Potenciana and the Colegio de Santa Isabel, lodged some 100 orphaned daughters of citizens and soldiers. ${ }^{7}$ This small Spanish community discovered early enough that commerce in the transpacific trade offered greater reward than any other possible livelihood. Trade yields far surpassed the benefits of an encomienda or income from agriculture or livestock production. Chinese immigrants lost no time in establishing a market in the city, making Manila an entrepôt for Asian goods and Mexican silver, and their Philippine-born descendants continued this line of work. Commerce was inextricably linked to the city, where every settler was a merchant. ${ }^{8}$

While the Chinese were at one end of the commercial circuit of the galleon, the Mexicans were at the other. All merchandise was sold in Mexico. This layout fostered a complex synergy between the merchants on both sides of the Pacific. Mexicans had seen the profitability of transpacific trade early on and taken an active interest in fostering and maintaining it. This had disturbed the wholesalers of European textiles in the Spanish peninsula, who mobilized in Madrid's court to restrict the arrival of Asian goods. Meanwhile, the citizens of Manila convinced the crown that without the galleon trade there would be little incentive to remain in the islands. Lobbying efforts from the two sides crystallized in the 1593 compromise legislation that permitted only Manilabased citizens to participate in the trade, banning Mexicans, and set a monetary limit to the galleon merchandise tonnage and its profit. ${ }^{9}$

Undaunted by the legal restriction, Mexican merchants resorted to subterfuges to continue in the business. They established commercial societies or partnerships with Manila citizens by sending factores, agents or partners of commercial

7. Alva Rodríguez, Vida municipal, 332-341; Memoria de las hijas de la Santa Misericordia que hay en este Colegio de Santa Isabel, Manila, December 1, 1665, Archivo Franciscano Ibero Oriental [hereafter AFIO], 46/35; Archbishop Miguel García Serrano to the king, July 25, 1621, Manila, AGI, Filipinas, 74, fol. 604r; Uriarte, Manifiesto y resumen, fols. 20r-2lv. For examples of social and economic networks, see Inmaculada Alva Rodríguez, "Ciudad y comercio en el siglo XVIII. El Galeón de Manila en el desarrollo de la vida municipal," and Consuelo Varela, "Microhistoria de un galeón: El Santo Niño y Nuestra Señora de Guía (1684-1689)," both in Un océano de seda y plata: el universo económico del Galeón de Manila, Salvador Bernabéu Albert and Carlos Martínez Shaw, eds. (Seville: CSIC, 2013), 179-201 and 229-246, respectively.

8. Merino, El cabildo secular, 39-54; Antonio García-Abásolo, "Españoles y chinos en Filipinas. Fundamentos del comercio del galeón de Manila," in España, el Atlántico y el Pacifico. V Centenario del descubrimiento de la Mar del Sur (15132013). Yotros estudios sobre Extremadura, Félix Iñesta Mena, Felipe Lorenzana de la Puente, and Francisco Javier Mateos Ascacíbar, eds. (Llerena: Sociedad Extremeña de la Historia, 2014), 15-17; García-Abásolo, "Private Environment," 355-357; Antonio García-Abásolo, La vida y la muerte en Indias. Cordobeses en América (Siglos XVI-XVIII) (Córdoba: Publicaciones del Monte de Piedad y Caja de Ahorros de Córdoba, 1992), 5.

9. Luis Alonso Álvarez, "E la nave va. Economía, fiscalidad e inflación en las regulaciones de la Carrera del Mar del Sur, 1565-1604," in Bernabéu Albert and Martínez Shaw, eds., Un océano de seda y plata, 25-84. 
houses representing their interests. They also took advantage of the fact that Manila was strapped for both cash and capital. Some of the most daring Mexicans even resettled in Manila for a few years, thus not only obtaining galleon loading rights, but also getting to know the market and creating or partaking in commercial networks. In other cases, rich traders commissioned relatives to relocate, and many of these men made the archipelago their permanent home. A trading career in Manila usually started with obtaining a post in the military or the colonial government. Navy assignments in the galleon were the most coveted, especially those of commander and silver guardian, which came with large loading rights and facilitated smuggling. ${ }^{10}$ Commercial and financial interdependence and fluid migration carved strong ties between merchants on both sides of the Pacific.

\section{The Performance of Charity in The Misericordia}

In 1594, in the thick of the demographic drive and after 20 years of replicating Spanish urban culture, Manila's elite felt that a pious welfare society was missing. Back in their urban localities in Spain, there was an extensive culture of lay societies, with their mix of encouraging devotional practices and promoting welfare. The respectable poor and other kinds of destitute were increasing, and sporadic charity was not enough to help them all. In 1594, the local oligarchy, presided over by the governor of the archipelago and including some of the first conquistadors and members of the city government, established the Hermandad de la Misericordia, the first lay confraternity of Manila. The presence of a few Portuguese religious and citizens in the city led to the choice of a Casa da Misericordia (House of Mercy), a type of lay society operating in Macao, Goa, and cities throughout Portugal. Immediately after its foundation, the regular beneficiaries of its alms were Spanish widows and orphans, disabled soldiers, and forsaken servants and slaves who were too sick to work. In addition, the confraternity helped prisoners and ransomed captives, and conducted funeral processions and burials of members, outsiders, and convicted criminals. It also took charge of executing wills. ${ }^{11}$

10. Louisa Schell Hoberman, Mexico's Merchant Elite, 1590-1660: Silver, State, and Society (Durham and London: Duke University Press, 1991), 39-41, 214-220; Yuste, "Comerciantes de México," 213-222; Yuste, Emporios Comerciales, 122-147, 295-316; Yuste, El comercio de la Nueva España con Filipinas 1570-1785 (Mexico City: UNAM, 1984), 40-42; Yuste, "Las familias de comerciantes en el tráfico transpacífico en el siglo XVIII," in Familia y poder en Nueva España. Memoria del Tercer Simposio de Historia de las Mentalidades (Mexico City: Instituto Nacional de Antropología e Historia, 1991), 67-73; Mariano Ardash Bonialian, El Pacifico hispanoamericano. Politica y comercio asiático en el Imperio Español (1680-1784) (Mexico City: Colegio de México, 2012), 175-198; García-Abásolo, "Private Environment," 361-365.

11. Lourdes Díaz-Trechuelo, "Religiosidad popular en Filipinas: hermandades y cofradías (siglos XVI-XVIII)," Hispania Sacra 5 (2001): 345-366. The following are overviews on Iberian confraternities: A. J. R. Russell-Wood, Fidalgos and Philanthropists. The Santa Casa da Misericórdia of Babia, 1550-1755 (Berkeley and Los Angeles: 
Membership was not large, usually between 100 and 200, although around 1668 the number must have been much lower, given the city's demographics. No complete list of members exists, so membership data has been collected from signatures on official confraternity documents. The confraternity was managed by a yearly elected mesa, or board, of 12 guardians and a proveedor, who was the head of the board and whose office translates literally as 'purveyor.' Like all confraternities and organizations of this sort, its statutes, which acquired an inalienable and sacred character, delineated the duties of the confraternity's members and set corresponding penalties for transgressors. From the start, the Misericordia attracted the colonial and local oligarchies, providing a civic-religious context wherein the usual kinship ties associated with this type of corporations were fulfilled. ${ }^{12}$

During the first four years, the confraternity financed its charities exclusively with alms and gifts. It did not take long before donors, in the wake of traditional strategies for the afterlife that became common after the consolidation of the doctrine of Purgatory in the Councils of Florence and Trent, took to establishing pious gifts in the form of legacies in perpetuity. ${ }^{13}$ Following the practices in Spain and Spanish America, those bequests were invested as liens (censos), which generated an annuity of five percent from real estate loans and created more stable resources. Earnings were apportioned among pious causes chosen by the donor. ${ }^{14}$ By 1621 , the Misericordia was managing 19 lien-based bequests with a real-estate capital of 69,400 pesos. The annual yield of 3,600 pesos was distributed as stipends for masses, alms for the indigent, and donations to religious

\footnotetext{
University of California Press, 1968); Manuel Cámara del Río, Beneficencia y asistencia social. La Santa y Real Hermandad, Hospitaly Casa de la Misericordia de Ceuta (Ceuta: Instituto de Estudios Ceutíes, 1996); Sá, Quando o rico se faz pobre; Sá, As misericòdias portuguesas; "Ordenanzas, y Constituciones de la Sancta Misericordia de la Insigne Ciudad de Manila reformadas conforme al estado, y disposiciones de la tierra por los Hermanos de la dicha Hermandad, conforme por las Ordenanzas de la Ciudad de Lisboa se dispone, y aunados a ella el año de 1606," Manuscript copy, July 22, 1621, in Fernando de los Ríos Coronel to king, AGI, Filipinas, 39, N. 6.

12. "Ordenanzas, y Constituciones," 1621; Uriarte, Manifiesto y resumen, fols. 1v-3r; Juan O. Mesquida, "Early Social Assistance in Spanish Manila: The 1606 Statutes of the Misericordia.” Synergeia, 3 (2009): 5-28.

13. Samul K. Cohn, Jr, Death and Property in Siena, 1205-1800: Strategies for the Afterlife (Baltimore and London: John Hopkins University Press, 1988), 161-184; Catechism of the Catholic Church (New York: Doubleday, 1995), nos. 1030-1032; The Canons and Decrees of the Sacred and Ecumenical Council of Trent, J. Waterworth, trans. and ed. (London: Dolman, 1848), 232-233, http://history.hanover.edu/early/trent.htm, accessed February 10, 2017. Spanish America inherited the practice. Schwaller, Origins of Church Wealth, 111-112; García-Abásolo, La vida y la muerte, 131-157.

14. On the economic practices of confraternities and similar Church-related institutions in Latin America, see Martínez López-Cano, von Wobeser, and Muñoz, eds., Cofradias, capellanías y obras pías; Ma. del Pilar Martínez López Cano, ed., Iglesia, estado y economía. Siglos XVI al XIX (Mexico City: UNAM \& Instituto de Investigaciones de Dr. José María Luis Mora, 1995); Martínez López Cano, Speckman Guerra, and von Wobeser, La Iglesia y sus bienes. For a detailed explanation of the lien (censo) in its different applications, see María del Pilar Martínez López-Cano, Crédito a largo plazo en el siglo XVI. Ciudad de México (1550-1620) (Mexico City: UNAM, 1995); Bauer, "The Church in the Economy"; and Schwaller, Origins of Church Wealth, 111-147.
} 
communities. ${ }^{15}$ Administering these legacies became one of the main duties of the Misericordia guardians, who had to maintain and rent out the properties with liens, and collect and distribute the interest. As laid down by the Council of Trent, testamentary gifts became sacred goods, and only bishops could alter what was stipulated in a will, and only if incontestably valid reasons were presented.

By 1645 the confraternity board was administering 33 liens with a real-estate capital worth 89,855 pesos of city houses and 69,510 pesos of rural houses, which provided a generous yearly income for its charities. As in the rest of the Spanish empire, liens were an important financial factor in Manila: they were used to provide credit. Other pious societies and even the city council oversaw liens, to the point that the majority of the houses of the city had lien obligations. This circumstance is very relevant to this study: when the city experienced the devastating earthquake of 1645, the value of real estate suffered such depreciation that all corporations administering liens experienced a large income reduction, and their capacity to provide alms (and credit) diminished. ${ }^{16}$

Faced with this revenue crisis, the board of the Misericordia decided in 1656 to transfer a hospital for former slaves and servants, and destitute Spanish and mestizo women, that it had been running since 1596, to the Order of San Juan de Dios. The confraternity was then freer to concentrate on maintaining its main undertaking, the Colegio de Santa Isabel, a boarding facility for orphaned Spanish and mestizo girls that it had established in 1634, and whose finances were always in the red. ${ }^{17}$ The 1658 and 1665 earthquakes dried up the lien market, and revenues for charity dropped. ${ }^{18}$ The economy of pious largesse in Manila looked rather bleak, and this was aggravated even more by the demographic crisis experienced by the city from the 1650s to the 1670s.

15. Archbishop Miguel García Serrano to king, July 25, 1621, Manila, AGI, Filipinas, 74, fols. 596v-604r; Juan O. Mesquida, "The Early Years of the Misericordia of Manila (1594-1625)," Revista de Cultura (International edition) 14 (April 2005): 59-81.

16. Uriarte, Manifiesto y resumen, fol. 26v; Compromiso otorgado por los estados y comunidades de la ciudad para la nueva reducción de los censos impuestos en las casas y posesiones della por la ruina del terremoto de 1645, 1649, AGI, Escribanía de Cámara, 404-A; Alva Rodríguez, Vida municipal, 248-249; Burns, Colonial Habits, 157-167.

17. Uriarte, Manifiesto y resumen, fols. 4, 20r; king to mesa, December 5, 1659, Madrid, National Archives of the Philippines [hereafter NAP], Spanish Document Section (SDS) 19182, fol. 491; Juan O. Mesquida, "Spaces, Material Culture, and Changing Roles: The Misericordia of Manila (1594-1869)," in Into the Frontier. Studies on Spanish Colonial Philippines. In Memoriam Lourdes Diaz-Trechuelo, Marya Svetlana T. Camacho, ed. (Pasig City, Philippines: University of Asia and the Pacific, 2011), 187-219.

18. Juan de la Paz, Primera Clase, Consulta LXII, "Sobre si a un eclesiástico le es lícito el trato de correspondencia," Consultasy resoluciones varias, theologicas, juridicas regularesy morales... (Seville: Thomas López de Haro, 1687), 175-178, https://books.google.es/books?id=uHKWyuDNls0C\&pg=PP7\#v=onepage\&q\&f=false， accessed February 10, 2017; Juan O. Mesquida, "La población de Manila y las capellanías de misas de los españoles. Libro de registros 1642-1672," Revista de Indias 70:249 (May-August 2010): 486-489. 


\section{A REVOLUTIONARY IDEA}

It was at this dramatic junction that a Spanish merchant established a new type of pious gift, one that would turn the future of charitable institutions and the credit market of Manila around. In 1668, Captain Diego Martínez Castellanos, who was seriously ill, called for the proveedor of the Misericordia to inform him that he had decided to advance one of the terms of his will. Thus, he would entrust 3,000 pesos to the mesa of the Misericordia to create a pious legacy in perpetuity that would generate income from lending 1,000 pesos yearly at 40 or 50 percent interest to galleon traders. Earnings would replenish the original capital, and further gains would be assigned for the upkeep of the orphans of the Colegio de Santa Isabel and its facilities. If prospects were good, part of the money could be lent to traders with Cantonese or Javanese interests. If there were trade losses, donations for charity would stop until income from lending the rest of the capital replenished the seed money. Martínez Castellanos stated his desire for reliable borrowers with capable guarantors. Noncompliance with his terms would result in the transfer of the money to the Convento de Santa Clara. After his death one year later, the executor of his will added 927 pesos to his legacy. It was up to the mesa to decide who to lend the money to, and what kind of assurances to ask from borrowers. In 1669, the mesa lent the first 1,309 pesos from this endowment, at 40 percent interest. ${ }^{19}$

Martínez Castellanos's endowment made use of a respondentia loan (correspondencia de riesgo a premio de mar, in Spanish, or respondentia loan on maritime interest), which had been a common means of financing maritime trade since ancient times. ${ }^{20}$ It was used extensively to fund the Spanish Atlantic fleets and, closer to Manila, the Portuguese in Macao availed of them to trade with Japan. ${ }^{21}$ According to Fr. Juan de la Paz, a Dominican based in Manila, it was also common in Manila around 1680. Its high interest rates were not considered usury by many contemporary moralist theologians because the setup between the lender and the borrower was akin to a trading company, with the former acting as the financier (what in modern terms is known as an equity investor). The borrower used the loan to buy merchandise, ship it in the

19. Del testimonio de las diligencias que ejecutó la Hermandad de la Misericordia de Ciudad de Manila para reformar, corregir y añadir algunas ordenanzas antiguas . . Manila, 1756, AGI, Filipinas, 596, fols. 65r-67v. The document contains sections of original documents from 1668 and 1669.

20. Another type of loan on maritime interest was the bottomry loan in which the borrower mortgaged his ship as collateral in case he could not meet his obligations. This was not necessary in Manila since the galleons plying Acapulco were sponsored by the crown.

21. Antonio-Miguel Bernal, La financiación de la Carrera de Indias (1492-1824). Dinero y crédito en el comercio español con América (Seville: Fundación el Monte, 1992), 123-207; C. R. Boxer, Fidalgos in the Far East, 1550-1770 (London: Oxford University Press, [1948] 1968), 114-121. 
galleon, sell it in Mexico, and bring back the earnings in a Manila-bound galleon. He had to pay back the interest and the principal as long as the boat reached its destination, whether the sale was profitable or not. If any mishap occurred while crossing the ocean either way-a fire, shipwreck, or capture by an enemy ship_-and the merchandise or the return silver were lost completely, the lender forfeited the capital loaned and the interest gain. The lender could command the seemingly exorbitant interest of 40 to 50 percent because of the high risk he incurred. Partial losses demanded the proportional repayment of the saved portion of merchandise or silver. The lender decided the loan's assurances, usually requiring the borrower to mortgage the loan over his person and goods, and provide backers, although in Manila the latter did not seem to assume any financial obligation. ${ }^{22}$

Why did Martínez Castellanos choose a respondentia loan rather than a lien to finance his charity? ${ }^{23}$ His fundraising choice was the result of looking for a more effective means than the lien to offer some credit from which to generate a steady income for his pious gift in the credit market of Manila at that time. As explained earlier, property-based liens were no longer attractive, since there were too many of them and their value had been severely depreciated. ${ }^{24}$ Due to the galleon trade, there was a high credit demand in Manila but credit options were limited. From our present viewpoint, the extent of the use of respondentia loans in Manila at the time of Martínez Castellanos's legacy is unclear. Only merchants with excess capital could afford giving them, and Manila had then few wealthy traders willing to earn less than they would if they used the money themselves and willing also to assume the maritime risks. ${ }^{25}$ Existing documentation records the presence of at least two rich traders who engaged in

22. De la Paz, Consulta XLIX, "Que trato sea el que en estas islas llaman de correspondencia ..., " Consultas y resoluciones, 129-136. In the fifteenth and sixteenth centuries, there had been much debate on the morality of respondentia loans, but most moralists had ceased to consider it usury by the beginning of the seventeenth century, due to a better understanding of economics. The interest in this type of loan was considered a form of insurance that the lender had a right to charge, since he assumed a great risk. Besides, Spanish monarchs used their influence to avoid moral objections to the practice, which was vital for the trade with America, and the royal coffers. Bernal, $L a$ financiación de la Carrera, 40-42, 68-71, 103-104, 198-203. Yuste explains the regulations for respondentia loans in the Spanish consulate of Bilbao in 1737, in "Obras pías en Manila," 183-185.

23. A few months earlier, the priest Manoel Pereira founded the first respondentia endowment with less stringent conditions in the Misericordia of Macao on October 31, 1667, but there is no evidence that Martínez Castellanos knew of it. Arquivo Histórico de Macau [hereafter AHM], Santa Casa da Misericórdia (SCM), fol. 304.

24. Eleven persons created pious works based on liens in the Misericordia after 1645, but after a few more earthquakes, they preferred to donate a farm or shops that would be leased out rather than used as mortgages. "Demonstración de las fundaciones que administra la Real Casa de la Santa Misericordia de Manila, cuyos capitales se hallan colocados a censo . . . January 16, 1790," AGI, Filipinas, 856; Mapa 6, financial statement, 1779-1783, AGI, Filipinas, 595.

25. De la Paz, Consultas y resoluciones, Consulta XLIX. He also mentions that Manila-based merchants, aside from borrowing respondentia loans, entrusted their merchandise to other traders in the galleon to sell in Mexico, paying them 18 to 20 percent of the earnings. 
large-scale lending, but there are no studies regarding respondentia loans before Martínez Castellanos's legacy. ${ }^{26}$

This type of loan was appealing to merchants because of the expected high returns from the galleon trade, and the added benefit of not requiring collateral. However, they were not easily awarded. Borrowers needed to fulfill two requirements: evidence of their good character and business capacity, demonstrated in a good repayment record. The capability to earn was easier to demonstrate because transpacific trade was promising, but being deemed trustworthy required time, experience, and trading networks. ${ }^{27}$ Therefore, from the viewpoint of the investment, as Martínez Castellanos had envisioned, a respondentia-based pious gift offered good security, since the board of the Misericordia would have to be very careful with the credentials of the borrower. The sacred character of the legacy and the commitment of the Misericordia to respect its terms would further assure the viability of the endowment, and encourage the donor to entrust it to them.

Other credit sources were not applicable to finance pious gifts. Most of them originated from Mexican sources. The most common means to get cash was through commercial companies or agreements between merchants on both sides of the Pacific, as mentioned above. The documentation also speaks of another financing option, especially present in times of money scarcity, when Mexicans sent capital under cover "in trust" to Manila merchants, who would buy the merchandise and ship it in the galleon to the Mexican agents in Acapulco. Manila merchants gained 10 percent of the sent silver, and it was free of risks, for they earned it even if the galleon suffered any mishap. ${ }^{28}$ This exchange entailed only modest gains, but it was an effective way for newcomers or citizens with little capital to start making a profit. The Chinese did not lend capital but sold on credit, although at present there are no records of the interest rates that they charged, and it can be surmised that they did so only with reliable merchants. ${ }^{29}$

26. This research has found only two Manila traders who also engaged in lending during the seventeenth century. However, the documentation used does not prove that they did so before 1668. Diego de Palencia was known for having lent profusely by the time of his death in 1680, with interest rates of 40 percent and 50 percent, denoting that he was using respondentia loans. Marcos Quintero Ramos was also a lender, starting most likely some years after he received an inheritance from his uncle Pedro Quintero in 1679. See Alva Rodríguez, Vida municipal, 306-307, 310; and Documents related to the inheritance of General Marcos Quintero Ramos, Manila, 1703-1715, AAM, 8.D.10, folder 4.

27. Goods in Acapulco could be sold at prices between 1200 percent and 1600 percent higher than in Manila, and Mexican importers' net profit was in the range of 400 to 600 percent. Bonialian, El Pacifico hispanoamericano, 176-177.

28. Yuste, Emporios transpacificos, 139-145, 295-316. Holding Mexican money in trust had been a common practice among the first batches of settlers, who had no capital of their own to trade in the galleon. Manila citizens continued availing themselves of it as a credit source in times of necessity. Juan de la Paz, O.P., Consultas del P. Paz, Archives of the University of Santo Tomas [hereafter AUST], Libros 188, fols. 25v-26r, 35r-36v.

29. Alva Rodríguez, Vida municipal, 79-80, 87; Joshua Kueh, "Adaptive Strategies of Parián Chinese: Fictive Kinship and Credit in Seventeenth-Century Manila," Philippine Studies 61:3 (2013): 371-376. 
In terms of generating revenues for charity, the new type of legacy had clear advantages over those based on real estate. A lien of almost 4,000 pesos could generate only 200 pesos a year, while one-third of 4,000 pesos at 50 percent interest could fetch earnings of more than 650 pesos, and even more if another third was lent at 20 percent in the Asian trade. A disadvantage of the new legacy is that, while rent from liens could be collected in a year's time, it usually took several years for respondentia-based bequests to garner the stipulated seed capital that would allow for the distribution of alms.

Martínez Castellanos's life offers some cues to explain his choices of charity and charitable investment. Born in Viguera, a small town near Logroño, Spain, the merchant had arrived at Manila in 1643, and soon after witnessed the destruction of the city caused by the 1645 earthquake. In 1647 he joined the defense forces assembled against a Dutch attack, and a few years later the archbishop appointed him treasurer of the reconstruction works of the Manila Cathedral. He used Mexican capital to trade. In 1655, Mexican merchants Lieutenant Domingo de Bastidas and Cristóbal de Sosa sent him in the St. Francis Xavier galleon 20,735 and 6,000 pesos respectively as a trust (en confianza) to purchase Asian goods for them. Unfortunately, the ship ran aground, and the funds were confiscated by the government, which suspected that it was Mexican money. Martínez Castellanos rejoined the army to repel a Chinese corsair in 1662, and again during the 1663 Chinese revolt. By 1664, the cathedral was almost finished. Although he did not earn a wage for his work, he had administered the renovation funds, had convinced a friend to change the beneficiary of a testamentary gift to help in the construction, and had even advanced money of his own. At that time, the money from the St. Francis Xavier had not been returned to him, and he declared himself insolvent and unable to help his parents and sisters in Spain. Nevertheless, he was conducting trade through his younger brother Pedro, who was his agent in Acapulco. ${ }^{30}$

Martínez Castellanos's legacy was the culmination of a lifelong involvement in the affairs of the community. A committed citizen who did not miss a chance to help when needed, he picked as his pious cause the socially indispensable and financially deprived Santa Isabel. At the time of his endowment, the colegio had 45 boarders and three external female students, and it performed a key social function, offering boarding facilities and basic education to the future brides of the Spanish men in the midst of the city's worst demographic crisis. ${ }^{31}$

30. Diego Martínez Castellanos to archbishop of Manila, July 12, 1664; Pedro Martínez Castellanos to Diego Martínez Castellanos, March 28, 1655, Acapulco; both in Pleito que siguen los vecinos de esa ciudad acerca del entro de la plata que salió a tierra del naufragio del Galeón San Francisco Xavier viniendo de la Nueva España el año pasado de 1655, AGI, Escribanía de Cámara, 404A.

31. Memoria de las hijas de la Santa Misericordia ..., December 1, 1665, AFIO, 46/35. 
No less important were the spiritual benefits of his pious gift in the face of the afterlife, which included the girls' prayers for their benefactor. Furthermore, his endowment through the Misericordia would leave a lasting memory in the spiritual and material economies of the city since the funds of his donation would be kept separately and bear his name. Borrowers and the colegio administrators would remember Diego Martínez Castellanos for generations to come. From the viewpoint of the financing choice, he was well acquainted with the credit market of Manila and knew that there would always be some trader with a good enough credit record to take the loan. Dividing the loan in three shares and keeping one in reserve was a strategy prudent enough to preserve capital to make it grow again in case of losses.

\section{The NeW Charitable Investment Consolidates}

The advantages of this innovative fundraising legacy did not go unnoticed by the members of the mesa of the Misericordia, who easily accepted its terms in a regular meeting of the board on February 23, 1668. In fact, the mesa did not in this instance comply with the confraternity's statutes regarding new financial obligations, which required seeking the advice of two theologians and two lawyers, and subjecting the decision to a general assembly of the membership. Neither did it request permission from the ecclesiastical authorities as laid down by Trent. The latter omission was consistent with the confraternity's modus operandi, which from the start had remained autonomous from the archbishop and his curia.

The violation of its own statutes may have been due to the confraternity's small membership during the population nadir of Spanish Manila, but it was also consistent with a management style that the treasurer of the colonial government had denounced 30 years earlier. The members of the Misericordia, he claimed, were businessmen who never wasted an opportunity to make money. Some wills that contained liens or funds for the brotherhood could not be executed quickly (often because other heirs, property, or the deceased himself were registered abroad or resided elsewhere), so while waiting for the result of their queries, mesa guardians invested the money in trade and used the interest to sponsor their charities, and in some cases, their private enterprises. ${ }^{32}$ Guardians were also used to handle galleon funds, not just in their role as

32. Treasurer Juan Bautista de Zubiaga to king, July 25, 1638, Manila, AGI, Filipinas, 30, N.33; Del testimonio de las diligencias ..., Manila, 1756, AGI, Filipinas, 596, fols. 65r-67v; Juan O. Mesquida, "Negotiating Charity, Politics, and Religion in the Colonial Philippines: The Brotherhood of the Misericordia of Manila (1594-1780s), in Faith's Boundaries: Laity and Clergy in Early Modern Confraternities, Nicholas Terpstra, Adriano Prosperi, and Stefania Pastore, eds. (Turnhout, Belgium: Brepols, 2012), 187-206. 
merchants, but also as part of their role in administering the confraternity's income. The confiscated funds aboard the St. Francis Xavier of 1655 included 4,600 pesos that belonged to the Misericordia, which may well have been the result of a three-ton grant allotted by Governor Luis Pérez Dasmariñas in the galleon in $1594 .^{33}$ Dominican friar Juan de la Paz, giving his opinion on whether a priest could grant a respondentia loan, argued that the new type of legacy did not contravene canon law because the lender did not engage in business-only the borrower did. ${ }^{34}$ Above all, the Misericordia welcomed the new endowment to meet the constant need of funds for the Colegio de Santa Isabel, and why not, if it would introduce a new credit source for the beleaguered colony.

There was no rush among Manila's citizens to set up more such pious gifts (Table $\mathrm{A}$ in the annex lists all the legacies entrusted to the Misericordia, the donors, and some other relevant information). ${ }^{35}$ The second endowment of this sort was granted six years after Martínez Castellanos's death. In 1675, General Tomás García de Cárdenas donated 12,000 pesos to the Misericordia to create a similar legacy, which he modified three years later. As it happens, García de Cárdenas was the proveedor of the mesa when Castellanos created his endowment. It looks as if he had waited to see the outcome of the first legacy and, after realizing its potential, bet for higher stakes by taking a more daring stance. He determined that half (instead of Martínez Castellanos's third) of the capital be loaned out yearly, only in the galleon trade, and at a 50 percent interest rate. He specified that borrowers had to be "people of means, reliable, lay, and in good standing, and their guarantors acceptable.” If nobody met these requirements, no loans should be made. He also stated that the money could not be lent out as liens. One fourth of the earnings, or 3,000 pesos if the operation was successful, would be distributed yearly among the 15 beneficiaries that he had designated, and no others. If his

33. Uriarte, Manifiesto y resumen, fol. 3v; Pleito que siguen los vecinos ... del Galeón San Francisco Xavier . . 1655, AGI, Escribanía de Cámara, 404A. One ton was equivalent to eight bales, and each bale was valued at 150 pesos. See Alva Rodríguez, Vida municipal, 92; and Alva Rodríguez, "Redes comerciales y estrategias matrimoniales. Las mujeres en el comercio del Galeón de Manila (siglos XVII-XVIII)," Revista Complutense de Historia de América 42 (2016): 205.

34. De la Paz, "Sobre si a un eclesiástico le es lícito el trato de correspondencia," Primera Clase, Consulta LXII, Consultas y resoluciones, 173-180.

35. There were 59 respondentia endowments established under the care of the Misericordia between 1668 and 1810. I have listed the donors in Table A of the Annex, indicating the year in which they established the endowments. Another column displays whatever relevant social information was found. I have also added a column with the name of the will's executor. The next column contains the initial endowment, and the last column indicates the value the donor intended to reach after the investment of the original donation. This definitive capital was used to provide loans and it had to be replenished to the same level yearly. Donors allocated a yearly stipend for charity on condition that the definitive capital of the endowment be reached, although a few allowed the distribution of some money among beneficiaries even if the loans' returns were below the fixed capital. Cuenta en cargo y data que presentaron el Proveedor y diputados de la Hermandad y Casa Real de la Santa Misericordia, de la ciudad de Manila, al Señor Licenciado D. Francisco Enríquez de Villacorta . . . desde 22 de noviembre de 1754 . . . a 22 de noviembre de 1755, ... [This document will be cited hereafter as Cuenta en cargo y data . . 1755], NAP, SDS, 19165. 
conditions were not followed, his donation would be transferred to the rector (director) and professors of the Universidad de Santo Tomás. Just like the first legacy, distribution of the earnings to charity would stop if losses exceeded the principal of 12,000 pesos. ${ }^{36}$

Tomás García de Cárdenas was a prominent citizen of Manila when he established his legacy. He had been in the city government in 1653 and 1658, and was also an active member in the Misericordia, joining the mesa at least in 1649, 1656, and 1668. He had been one of the largest investors in the 1655 St. Francis Xavier galleon, with 40,111 pesos, which were also confiscated as Mexican monies. ${ }^{37}$ The legacy did not have the character of a testamentary gift, but García de Cárdenas was not young, and it would not be surprising if the afterlife and desires to be remembered in the confraternity were at the back of his mind. Half the earnings went for dowries and other needs of the girls in Santa Isabel, which was surely close to his heart after having experienced over time the responsibility of their upkeep as proveedor, and the rest was to be used to aid city beggars and certain religious communities. A bet for such a high-risk investment, coming from an experienced trader, indicates that he did not expect any galleon mishap, which suggests that respondentia loans charged high interests not only because of the risk but also because of the opportunity loss, or the higher revenues the lender would have obtained from using the money for trade himself. García de Cárdenas wanted to secure large endowment earnings to subsidize his charities.

The third legacy is rather atypical and confirms, because of who decided on the specifications of the money and the beneficiaries, its main purpose as charity fundraising. The endowment was set up with the money from the inheritance of the governor of the Philippines, Manuel de León y Saravia, who died intestate in 1676, entrusting Dominican friars Diego de San Román and Baltasar de Santa Cruz and Captain Marcos Quintero Ramos to dispose of his goods. The value of the former governor's property reached 250,000 pesos, which alone betrayed his illegal involvement in the galleon trade, the pecuniary advantage he had taken of his post, and the commercial network he must have had, of which we can safely presume Quintero was part. It is not surprising then that Fr. San Román, who was in charge of drafting the will, used all the money for pious gifts, perhaps as a form of restitution. The Dominican died nine months later and was unable to carry out the will, which Fr. Santa Cruz

36. Cuenta en cargo y data . . 1755, NAP, SDS, 19165, fols. 542r-544v; and Obras Pías. Sus Fundaciones, n.d., NAP, SDS, Obras Pías, Bundle I, fols. $1 r-4 r$.

37. Pleito que siguen los vecinos ... del galeón San Francisco Xavier . . 1655, AGI, Escribanía de Cámara, 404A; Alva Rodríguez, Vida municipal, 355, 395. 
did with the help of Quintero. San Román allotted 50,000 pesos to create a respondentia legacy in the Misericordia, and he wanted the money to grow to 75,000 pesos. He also earmarked 12,500 pesos for yearly distribution among 14 charities, if the revenues exceeded the established permanent capital. Dowries for Santa Isabel and the expenses of the Colegio were the largest beneficiaries. San Román and Santa Cruz did not allot any donations to their order. The gift was deposited in the coffers of the Misericordia in three installments between 1677 and $1680 .^{38}$

\section{FIRST CRISIS AND RESCUING EFFORTS}

It is around the time that Saravia's legacy was established that records of loans from the three legacies surface. The first known borrower to date was General Francisco Enríquez Losada, commander of the San Telmo galleon in 1680. He borrowed all of the disposable money from the legacies, 27,000 pesos. Born in Macao, most likely Portuguese, Enríquez had set roots in Manila, amassing enough merits to become a royal officer and an encomendero. According to Manila audiencia magistrate Diego Calderón y Serrano, the commercial involvement of a galleon commander contravened royal orders, but Enríquez Losada bragged in public about the loan. ${ }^{39}$ The second known borrower was likewise a galleon commander, the brother-in-law of Juan de Vargas y Hurtado, governor of the Philippines until 1684, who would later flee to Mexico to avoid being tried for unlawful trading. ${ }^{40}$ The choice of borrowers attests that the mesa of the Misericordia was following the donors' will regarding lending only to reliable borrowers, since traditionally the galleon's generals were proven merchants. However, not everything went as expected and just a few years later, the mesa complained to the king that Enríquez had refused to honor a loan of 1,000 pesos from one of the three legacies, arguing that unpaid debts hurt not only divine worship and charities, but also the welfare of those who borrowed from respondentia endowments (emphasis added). ${ }^{41}$ The last remark indicated how, even if there were still few selected borrowers, the new pious endowment had become another source of church credit in Manila.

38. Vicente de Salazar, O.P., Historia de la Provincia del Santísimo Rosario de Philipinas, China y Tunking, del Sagrado orden de Predicadores. Tercera Parte, en que se tratan los sucesos de dicha Provincia desde el año de 1669 hasta el de 1700. Compuesta por el R. P. Fr. Vicente de Salazar, Rector del Colegio de Santo Tomás de la Ciudad de Manila y Chancellario de su Universidad (Impresa en la imprenta de dicho Colegio y Universidad de Santo Tomás de la misma ciudad, 1742), 114-115; Cuenta en cargo y data . . 1755, NAP, SDS, 19165, fols. 544v-547r.

39. Diego Calderón y Serrano to king, June 3, 1680, Manila, AGI, Filipinas, 11, R. 1, N. 14.

40. Varela, "Microhistoria de un galeón," 233. $68 \mathrm{r}-69 \mathrm{v}$

41. King to Governor Gabriel de Curuzeiaegui y Arriola, June 15, 1687, Madrid, AGI, Filipinas, 341, L. 8, fols. 
Developments in the last decade of the century highlighted the risks of respondentia legacies, and now help us to understand why respondentia loans commanded such high interests. For three consecutive years, the galleon was unable to reach Acapulco. In 1692, the Santo Cristo de Burgos was forced to return to port; in 1693, the galleon vanished in the sea; and in 1694, the San José was shipwrecked at the island of Lubang. Most of the capital of the three respondentia endowments was lost, as the different shares of their capital were being lent yearly. They were saved from extinction through some small arrears that came from Mexico unexpectedly, but it would take some time of small and successful reinvestments before the endowment capital would reach the desired level and produced revenues for charity. Saravia's endowment, for instance, took such a long time to recover that it was still well below target as late as $1734 .^{42}$

Despite these losses, Manila's community still believed that galleon investments were the best means to establish pious gifts in perpetuity. The same year that the San José ran aground, city council officials and the city's major traders created another endowment with the 446 pesos raised from the sale of unclaimed goods recovered from the wreck. It was a logical choice since many goods were bought with loans lent by the Misericordia and were now without obligation of repayment. Marcos Quintero added 200 pesos to the legacy. In the same year, Alonso de Oponte y Andrade and José Vázquez y Urías created legacies of 8,000 and 4,000 pesos respectively as testamentary gifts, naming Quintero executor of the wills. It took him three years to collect all the money, which he deposited in three installments. Soon after, in 1698, Quintero established his own legacy of 4,000 pesos. And a year later, Tomás de Endaya, field marshal of the Royal Battalion, as well as member of the Misericordia, and formerly Quintero's close business relation but now at odds with him, founded a legacy with 8,000 pesos. ${ }^{43}$ By the end of the century, the Misericordia could lend 12,332 pesos more to traders, aside from the small amount of funds left over from previous legacies.

The trust of Marcos Quintero and Tomás de Endaya in respondentia endowments is significant, because they were among the most successful merchants living in Manila. Quintero had inherited the fortune and trading business of his uncle, Pedro Quintero, in 1679, about the time that he was disposing of Saravia's endowment. Endaya had arrived at the archipelago in 1669 as a military officer,

42. Cuenta en cargo y data . . . 1755, NAP, SDS, 19165, fols. 544v-547r; Obras Pías. Sus Fundaciones, n.d., NAP, SDS, Obras Pías, Bundle I, fols. $4 \mathrm{r}-7 \mathrm{r}$.

43. Cuenta en cargo y data . . 1755, NAP, SDS, 19165, fols. 547r-554r. Alva Rodríguez, Vida municipal, 311 ; Alva Rodríguez, "Redes familiares y relaciones comerciales en Manila: Francisco Atienza Ibáñez y Tomás de Endaya," in América en la memoria: conmemoracionesy reencuentros, Begoña Cava Mesa, ed. (Bilbao: Asociación Española de Americanistas, 2013), 1: $239-244$ 
risen through the ranks, and become one of the most influential persons in the islands as the right-hand man of successive governors. Both belonged to a reduced trading elite that had grown around the city government in the last quarter of the century and that, through family connections and political influence, supplied the largest share of the galleon's merchandise and controlled trading networks. This commercial gentry was extremely wealthy. When Quintero died in 1703 , his personal worth was estimated at 200,000 pesos. He was regarded as one of the first Spaniards in Manila to make a large fortune from trade and was known to be a creditor for smaller merchants. The few large-scale galleon merchants had developed stable partnerships with the larger Mexican trading houses and did not seem to need added capital. This becomes apparent when, during times of cash scarcity in the 1680s and 1690s, this group of rich merchants tried repeatedly to block Mexican capital sent under cover to be lent out to Manila citizens, calling on the Church to condemn it on the grounds that it contravened the ban on Mexican interests in the galleon. ${ }^{44}$

As what can be considered the foundational stage of respondentia endowments ends, it is hard to see in these gifts any intention other than providing generous steady revenues to the local charities, especially the Colegio de Santa Isabel in its struggles during the city's deepest crisis, establishing spiritual investments, keeping the memory of the donors' generosity, and supplying a moderate credit source for Manila-based galleon traders. All the benefactors were Manila-based, used their own wealth, and would not benefit much from supplying capital to Mexican traders. Beginning with García de Cárdenas, a renewed interest in Asian goods in the Mexican market, noticeable since 1670, reassured donors of the viability of their legacies. Not even the trade mishaps of the 1690s deterred new foundations, since they were considered to be accidents in what was still an economic upturn. ${ }^{45}$

\section{RAISINg FundS FOR PREFERRED CHARITIES}

After the turn of the century, the new legacies further emphasized their philanthropic nature. Six of them were set up by clergymen to finance their charities. In 1701, the Bishop of Nueva Cáceres, Andrés González, a Dominican, entrusted the Misericordia with 16,000 pesos, half of which had to be lent out in the galleon. González kept increasing his capital by lending half of it yearly until it reached 50,000 pesos in 1705 , and he wished to keep on

44. Documents related to the inheritance of General Marcos Quintero Ramos, Manila, 1703-1715; AAM, 8.D.10, folder 4; Alva Rodríguez, Vida municipal, 84, 305-311; Alva Rodríguez, "Redes comerciales," 208-212; Alva Rodríguez, "Redes familiares," 232, 235-244; De la Paz, Consultas del P. Paz, AUST, Libros 188, fols. 25v-26r, 35r-36v.

45. Yuste, El comercio de la Nueva España, 31-40. 
investing until it became 80,200 pesos. As long as the full capital was intact, his legacy allotted 18,000 pesos yearly to many charities. Most of his beneficiaries were related to the Dominican order, such as the Church of Santo Domingo, the Universidad de Santo Tomás, and the Beaterio de Santa Catalina. There were also 1,000 pesos allotted for masses for the souls in Purgatory in the Monastery of Santo Domingo in Madrid, Spain, and 6,000 for the same purpose but in his native province of Zamora, Spain. ${ }^{46}$

Another clergyman who saw the fundraising potential of respondentia legacies was the Italian prelate Juan Bautista Sidoti, who had come to Manila with papal legate Carlos Tomás Maillard Tournon in 1704 on their way to China. Sidoti collected 12,000 pesos from Manila neighbors, asking the Misericordia to lend out one third for trade with Mexico and another third for Asian trade until it reached a fixed capital of 40,800 pesos. His main beneficiary would be the Seminary of San Clemente, which the king had approved as a seminary for native students but which Archbishop Diego Camacho y Ávila, influenced by Tournon and Sidoti, had opened to students from other Asian countries. Eventually, the king would resent the interference in his royal patronage and close the seminary, and the donations were transferred to the Franciscans and their charitable undertakings. ${ }^{47}$ It is very likely that Sidoti's benefactors bore in mind that their donations would enter the Manila credit market.

More than ten years after Sidoti's bequest, three more members of the clergy entrusted their foundations to the Misericordia. Recollect friar Pedro de la Purificación wanted to earn money to redeem a lien owned by the Dominicans in his order's convent of San Juan de Bagumbayan. Francisco de la Cuesta, archbishop of Manila, intended to earn enough to generate stipends for masses and other devotions in the Church of La Ermita, dedicated to Nuestra Señora de Guía, and the Manila cathedral. The Jesuit father José Virdis expected to get funds to clothe some natives in the Marianas Islands who were under his order's care.

Around that time, some members of the Misericordia and their wives founded a devotional society and donated 700 pesos to initiate a legacy that would generate 1,000 pesos a year to sponsor suffrages for the dead of the Misericordia and their

46. Obras pias. Sus fundaciones, n.d., NAP, SDS, Obras Pías, Bundle I, fols. 14r-25r. A beaterio was a community of women who lived in a style similar to female religious orders but did not take perpetual vows, Asunción Lavrin, "Female Religious," in Cities and Society in Colonial Latin America, Louisa Schell Hoberman and Susan Migden Socolow, eds., 5th paperbound edition, (Albuquerque: University of New Mexico Press, 1986, 1993), 188.

47. Cuenta en cargo y data . . . 1755, Manila, NAP, SDS, 19165, fols. 561r-563r, 568v-576r; Obras pias. Sus fundaciones, n.d., NAP, SDS, Obras Pías, Bundle I, fols. 30v-4lr; Marta María Manchado López, "Desamparo en que con la vida, se pierde el alma.' Las controversias en torno a la obra pía del Abad Sidoti para la recogida de niños chinos abandonados (Filipinas, 1705-1740)," Revista de Indias 71:252 (2011): 421-422. For further readings on the Sidoti case, see Pedro Rubio Merino, Don Diego Camacho y Ávila, Arzobispo de Manila y de Guadalajara de México (1695-1712) (Seville: Escuela de Estudios Hispano-Americanos, 1958), 424-433. 
relatives. The three clergymen did not stipulate a large capital before lending, but the Misericordia brothers set it rather high, at 6,000 pesos. Nicolás de la Vega Carballo, probably a priest, also envisioned his legacy as an investment instrument. In 1712 he left 2,500 pesos in his will for a foundation that would provide yearly stipends to five orphans, still minors, and then bestow 500 pesos for each of them upon their marriages, or their joining the clerical or religious state, or their turning 24 years old. If any died, which one did, the remaining money would be assigned for alms to the indigent sick. In time, the surviving four received their gifts. ${ }^{48}$

In 1701, the same year that Bishop González entrusted the confraternity with his legacy's initial capital, former city councilor and prosperous merchant Antonio Basarte set up a legacy in the Misericordia with 3,000 pesos. He died two years later, and his will ordered his legacy's increase with 47,000 more pesos to be obtained from the sale of his property. It was only in 1708, after his many debts were settled, that the Misericordia received 9,849 pesos, which it repeatedly lent out until they added up to 50,000 pesos. Thus, the beneficiaries of the 6,000 pesos he had assigned to various charities did not receive their first alms until 1726. Part of the reason it took so long was because Basarte had stipulated that only one-fourth of his money be lent out yearly for the trade with Mexico, at a fixed interest rate of 50 percent, to preempt the possibility of the funds' extinction due to seaborne calamities. ${ }^{49}$

These legacies, all established in the first two decades of the century, increased the capital available for borrowing at a moment when the capital of the previous legacies was still recovering. In 1705, the St. Francis Xavier galleon had disappeared at sea and wreaked havoc again on both old and newer pious bequests. Three years later the first 13 respondentia legacies of the Misericordia had a capital of 94,247 pesos. This was much less than the 152,276 pesos that had been donated, but traders could not help but be pleased with this new source of loans. ${ }^{50}$

\section{MEXICAN PRESENCE IN THE Misericordia}

Around this time, when the Misericordia and the other Obras Pías were becoming significant lending institutions for the transpacific trade, confraternity

48. Cuenta en cargo y data . . 1755, Manila, NAP, SDS, 19165, fols. 568v-569v; Obras pias. Sus fundaciones, n.d., NAP, SDS, Obras Pías, Bundle I, fols. 41r-57r.

49. Cuenta en cargo y data . . 1755, Manila, NAP, SDS, 19165, fols. 559r-561r; Obras pias. Sus fundaciones, n.d., NAP, SDS, Obras Pías, Bundle I, fols. 25r-30r.

50. Relación de las obras pías que administra la mesa de la Santa Misericordia de la ciudad de Manila, June 5, 1708, Manila, AGI, Filipinas, 290. Governor de León's legacy was the worst hit by the 1705 galleon wreck, with only 4,029 pesos left from the initial 50,000. Sidoti's endowment of 21,000 pesos was then worth only 15,937 pesos. 
documentation confirms the presence of members of Mexico City's transpacific trading cartels in Manila, both as guardians of the mesa and legacy founders. Their presence coincides with the early eighteenth-century phenomenon of large-scale migration of relatives, friends, or associates of important Mexican merchants to Manila, which Carmen Yuste has described. The diaspora was closely associated with a higher demand in America for Chinese textile products, which competed favorably with the more expensive European fabrics. Such competition was generated after Mexican traders traveled to the Philippines and China with European samples of textile goods and convinced the Chinese to sell them products of similar or better quality. The presence of Mexican traders in Manila was not new, but unlike the more strategic and temporary moves of the seventeenth century, many immigrants intended this time to settle in the Philippines and become local merchants who could use their strong ties with Mexican trading networks to their advantage. ${ }^{51}$

Among the leaders of the Misericordia of this period, four wealthy merchants stand out because of their network of Mexican relatives and associates: Domingo Antonio Otero Bermúdez, Juan Manuel Pérez de Tagle, Pedro González del Rivero y Quijano, and Francisco Carriedo y Peredo. They had acquired resident status in Manila, occupied military posts, and joined the city government. Otero Bermúdez and Carriedo y Peredo moved to Manila to manage the Asian leg of the commercial company created in Mexico by Pedro de Otero Bermúdez and Antonio de Echandía Otero. Pérez de Tagle and González del Rivero had been galleon commanders at one time, and in the 1730s they requested and obtained the titles of Marqués de las Salinas and Marqués de Montecastro y Llanahermosa, respectively. All but Carriedo y Peredo had been commercial associates of Governor Fernando Valdés Tamón, amassing great fortunes in the 1730s. They kept their political clout with Governor Gaspar de la Torre y Ayala. For his part, Carriedo married Governor de la Torre's daughter. They all established their own pious legacies in the Misericordia and were executors of others' testamentary bequests. Other donors, like Pedro Basilio de la Vega, Gaspar Carlos de Andrade y Villapol, María Joaquina Collantes Peredo y Trillanes, Domingo de Tembra, or Governor Gaspar de la Torre y Ayala himself, were relatives or commercial relations of the four, and were equally involved with Mexican commercial networks. ${ }^{52}$

51. Yuste, "Familias de comerciantes," 65-73; Yuste, Emporios transpacificos, 122-147, 295-316. Several testimonies confirm the arrival in the 1680s of large numbers of Mexican merchants in Manila. Increased involvement of Mexicans in the galleon trade is also attested by the many royal decrees issued during those decades against it, and the temporary banning of the silk trade in the galleon in the 1720s. See Bonialian, Pacifico hispanoamericano, 65-79, 178-179.

52. Pedro Luengo Gutiérrez, Intramuros: arquitectura en Manila, 1739-1762 (Madrid: Fundación Universitaria Española, 2012), 130-132; Yuste, Emporios transpacificos, 130-138, 302; Juan de la Concepción, Historia general de Philipinas (Manila: En el Convento de Nuestra Señora de Loreto del Pueblo de Sampaloc, 1791), 11:95. 
These four men were very active in the management of the Misericordia. Carriedo was the proveedor in 1727, when the mesa decided to create two respondentia endowments with the unclaimed money from the will of a Portuguese merchant, which began the trend of creating high capital, as is explained below. Otero was the proveedor in 1729, the year he created his first legacy. The two marqueses would also become proveedores. Moreover, all were in the junta or mesa of the Venerable Orden Tercera de San Francisco, the second lending institution in town. Otero was also the administrator of the respondentia legacies of the Beaterio de Santa Catalina and of one private donor. ${ }^{53}$ This direct involvement in the government of the Obras Pías was clearly an advantage to accessing such a large credit line. Networking and preferential treatment in the use of these funds was confirmed in 1728 by the cathedral provost, who happened to be a Misericordia member, and who identified borrowers as relatives, friends, and relations of the confraternity's members. ${ }^{54}$ Preferring relations and members of their own commercial families was reasonable considering the trustworthiness required from borrowers. It is not hard to see in this new stage of the endowments that the growing potential for obtaining credit from pious gifts further attracted Mexican migration, and that the newcomers in turn added more legacies and increased the amount of capital that could be loaned.

The presence of traders with close ties to Mexican commercial houses in the confraternity and its legacies ran parallel to more conservative commercial approaches in lending conditions after 1722. Instead of half the capital, new donors allowed only one-third of the principal to be loaned. They also set rather high cutoff points for capital, below which the Misericordia could not disburse any money for their choice charities. Most donors gave between 1,000 and 8,000 pesos but wished to increase the capital several-fold to reach a final principal between 12,000 and 36,000 pesos. Loans were extended to the Asian trade, which offered lower interest rates, between 10 and 20 percent, but was less risky than the galleon. These new strategies reflected donor apprehension regarding the near-depletion of funds caused by past mishaps. A fourth feature, lending at variable market interest rates rather than a fixed rate of 50 percent, aimed at enticing borrowers. ${ }^{55}$ A consequence of this novel approach was that capital had to be lent for longer periods before it could reach the funding levels that allowed charity disbursements.

53. Cuenta en cargo y data . . 1755 ..., Manila, NAP, SDS, 19165, fols. 569v-628r; AGI, Filipinas, 234; Libro de las constituciones municipales de Nuestra Sagrada Orden Tercera de Penitencia de NSP S Francisco (Impreso en el Convento de Nuestra Señora de Loreto en el pueblo de Sampaloc, 1746). Testimony of the notaries public pertaining to the contracts of obras pías in the Sacra Familia galleon', September 25, 1722, Archivo Histórico Nacional [hereafter AHN], Madrid, Clero, Jesuitas, 93.

54. Fr. Manuel Antonio de Ocio y Ocampo to king, July 5, 1728, AGI, Filipinas, 234.

55. Cuenta en cargo y data . . 1755, Manila, NAP, SDS, 19165, fols. 552v-580r. 
Between 1722 and 1785, when pious gifts slowed down, there were 34 new pious endowments based on respondentia loans in the confraternity. Twenty were testamentary gifts with a view toward the afterlife. The Marqués de las Salinas wished only to sponsor masses for the soul of his deceased wife. Five other endowments had various intentions, and the other eight were set up to finance specific undertakings. A few were created after the economy of Manila was brought to a halt with the capture of the Covadonga galleon in 1743 by the British, the return to port of the galleon loaded with merchandise in 1744, and the temporary suspension of galleon trips. The trader Simón de Amechesurra created a legacy to get extra income for the Hospital de San Lázaro, which he administered. Fr. Manuel Maldonado de Puga did the same to provide for the needs of the Order of San Juan de Dios, and Bishop Juan de Arrechederra, who was interim governor of the archipelago, wished to alleviate the needs of the indigent in jail. In 1784, administrators of several Obras Pías, the Misericordia among them, created a legacy to recover the bad loans of borrower and frigate owner Matías Suárez, showing the worth of these legacies as investments. ${ }^{56}$ Thus, because most legacies were testamentary bequests, or created by clerics, or to alleviate some financial need, there are no traces of Mexican money in this set of endowments.

The establishment of respondentia pious legacies slowed down toward the middle of the century for reasons that shall be explained later. Among the last respondentias established in this period, two differ markedly from the others. The first was set up by Francisco Echeveste through his will, read at the time of his death in 1750. Echeveste had arrived in the Philippines from Mexico in 1715 to serve in the army. Through his commercial network and social skills, he managed to get himself appointed to command the galleon three times. After saving enough capital, gaining experience in the transpacific trade, and consolidating a network of merchants, he returned to Mexico in 1727, where he created a commercial company with two other partners. Francisco Sánchez de Terán and the aforementioned Juan Manuel Pérez de Tagle would manage the company's commercial interests in Manila. ${ }^{57}$ Echeveste bequeathed 50,000 pesos for a respondentia legacy, which the Misericordia received in two installments in 1756 and 1757. Echeveste stipulated that his capital had to grow to 100,000 pesos before any giving of alms, and surprisingly, he destined very little of his legacy's huge earnings to charity. A similar case took place 20

56. Cuenta en cargo y data . . . 1755, Manila, NAP, SDS, 19165, fols. 576r-628r; Junta extraordinaria de examen de cuentas de la Real Casa de la Misericordia, February 12, 1889, Manila, NAP, SDS, 19182, fols. 402r-407r; Antonio García-Abásolo, "Una comunidad amenazada. Manila a mediados del siglo XVIII," in Entre Puebla de los Ángeles y Sevilla. Homenaje al Dr. JA Calderón Quijano (Seville: Escuela de Estudios Hispanoamericanos (CSIC) and Universidad de Sevilla, 1997), 355-356.

57. Yuste, Emporios transpacificos, 131-132. 
years later, when Felipe Iriarte, another Mexican merchant who had also spent some time in Manila, bequeathed 21,124 pesos as a testamentary legacy to the Misericordia. With a smaller target capital of 30,000 pesos, Iriarte also allotted little for charity. ${ }^{58}$ These legacies may have been motivated by gratitude, since both donors had previously benefited from the Misericordia funds, and surely expected spiritual dividends, but the circumstances and conditions of the endowments point toward wishing to bequeath an infusion of capital to a fund that could be tapped by some commercial relations. A window to those networks emerges from the in no way minor coincidence that the one who provided the small amount due to complete Echeveste's capital was General Juan Infante, the proveedor of the confraternity, paying back a commercial debt.

The last six legacies entrusted to the Misericordia were donated in the first decade of the nineteenth century. Two of them had small capitals and aimed at producing some quick capital to shoulder the expenses of boarders in the Colegio de Santa Isabel. The other four came from two well-known merchants, Luis Platé, who donated 16,000 pesos; and Felipe de Ceraín, who left almost 90,000 pesos in his will to create three respondentia bequests. Ceraín's career followed that of many previous donors, from military positions to engagements in trade. The earnings of the legacies of both benefactors were to be used as suffrages for themselves and their families, and to help Santa Isabel and the sick indigent. ${ }^{59}$

\section{LEGACIES AS CREDIT LINE}

The history of the legacies' money in the galleon trade verifies the effectiveness of the bequests as forms of credit. Table 1 illustrates the capital growth of endowments handled by the Misericordia. The table shows the amounts donated, the seed capital targets after which earnings were appointed for charitable causes, and the actual assets reported by the Misericordia. Actual assets included the cash in the coffers, which was usually less than 30 percent of the assets' total; the loans and the premium to be collected for that year; the returns left over from previous trading seasons; and unpaid debts or losses.

The table confirms the analysis of the funds outlined so far. First, it makes evident the large amounts made available for credit. Second, it indicates the

58. Estado general y circunstanciado de las obras que se hallan bajo la Administración de la Real Casa de la Santa Misericordia, n.d.; AAM, 9, A.1., Obras pías (1615-1919), folder 2C; and Obras pías. Sus fundaciones, NAP, SDS, Obras pías, I, fols. 231v-237v; Yuste, Comerciantes de la ciudad de México, 217.

59. Estado general y circunstanciado de las obras que se hallan bajo la Administración de la Real Casa de la Santa Misericordia, n.d., AAM, 9, A.1., Obras pías (1615-1919), folder 2C; Obras pías. Sus fundaciones, NAP, SDS, Obras pías, Bundle I, fols. 242r-25lv; Mesa de la Misericordia, Financial Statements, 1804 to 1823, AGI, Filipinas, 595. 
PIOUS FundS ACROSS THE PACIFIC (1668-1823) 685

TABLE 1

Capital of Respondentia Endowments (in pesos), Misericordia Confraternity

\begin{tabular}{llcc}
\hline Year & $\begin{array}{l}\text { Initial Capital } \\
\text { Given by } \\
\text { the Donors }\end{array}$ & $\begin{array}{l}\text { Intended Capital } \\
\text { before Alms } \\
\text { were Allowed }\end{array}$ & $\begin{array}{l}\text { Capital Reported } \\
\text { by the Mesa }\end{array}$ \\
\hline 1708 & 152,722 & 293,200 & 94,247 \\
1722 & 160,024 & 307,050 & - \\
1741 & 214,942 & 569,550 & 217,763 \\
1755 & 270,940 & 746,550 & 577,738 \\
1765 & 320,940 & 846,550 & 669,644 \\
1778 & 343,064 & 878,550 & 872,209 \\
1783 & 356,564 & 902,550 & $1,037,449$ \\
1814 & 485,684 & $1,031,670$ & 745,425 \\
1823 & 485,684 & $1,031,670$ & 941,274 \\
\hline
\end{tabular}

Sources: Relación de las obras pías que administra la mesa de la Santa Misericordia de la ciudad de Manila, June 5, 1708, Manila, Archivo General de Indias [hereafter AGI], Filipinas, 290; Minutes of the Mesa, October 11, 1741, Manila, National Archives of the Philippines [hereafter NAP], Spanish Document Section (SDS), 19165, fols. 185r-201v; Estado individual por quinquenio . . . 1750-1754, NPA, SDS, 19075, fols. 248r-257r; Mesa de la Misericordia, financial statements, 1765-1823, AGI, Filipinas, 595.

difficulties encountered during the first 50 years, which were aggravated by the risky terms imposed by the donors. Third, the biggest increment in donations happened between 1722 and 1765, coinciding with an upturn trend of the galleon commerce and a period when the Manila-based commercial elite with ties to Mexico City merchants was in power in the Misericordia. Table 1 also reveals that it was only during the last quarter of the eighteenth century that the funds reached the goal intended by the donors, and were thus robust enough to subsidize their preferred charities on a continuous basis.

Respondentia endowments were an important source of credit for galleon merchants for more than 100 years. In 1722, some 54 years after Martínez Castellanos's first legacy, respondentia loans from Misericordia endowments financed one-third of the galleon merchandise of the Sacra Familia $(97,823$ pesos), while the other Obras Pías lent another third $(92,671$ pesos), at a time when the maximum cost of the galleon merchandise was 300,000 pesos. Merchants could borrow from different lending corporations or administrators, and could be borrowers and simultaneously guarantors of other merchants, in what constituted dense trading networks. ${ }^{60}$ Four years later, the Santo Cristo de Burgos carried 120,000 pesos worth of merchandise from loans by the

60. Testimony of the notaries public pertaining to the contracts of obras pías in the galleon Sacra Familia, September 25, 1722, AHN, Clero, Jesuitas, 93. 
Misericordia. ${ }^{61}$ The few records available show that when the crown raised the ceiling of the galleon's merchandise to 500,000 pesos in 1734, the Misericordia continued providing loans that together averaged one-third of the total capital needed to finance the galleon trade. Likewise, after 1769 when the new limit of the galleon load was increased to 750,000 pesos, the Misericordia managed to lend amounts over 200,000 pesos per galleon trip from 1774 until the end of the trade with Mexico in $1821 .^{62}$

Credit demand in those high figures is sufficient proof of the appeal of respondentia loan endowments. As explained earlier, the creditor, in this case one of the Obras Pías, assumed the maritime risks, which was no insignificant advantage. Interest rates were high, but the expected return on investment was a lot higher. Many new settlers, short of cash but with plenty of enthusiasm, and almost inevitably with some friends in the trading networks, could avail themselves of these loans, especially after the first quarter of the eighteenth century, when trade was stabilizing and population was steadily increasing. Moreover, like most religious institutions, Obras Pías were more lenient with payment delays, and exhausted all possible means before going to court.

Not much attention is given here to the loans dispensed by the Misericordia for the Asian trade because the amounts were much smaller, and because that commerce was ultimately oriented to provide merchandise for the galleon. ${ }^{63}$ Also, the trading data of this study does not include smuggled goods. It is well known that the value of contraband in the galleon could be two to ten times higher than the legal load, but due to its illegal nature, information is scarce and not easily verifiable. ${ }^{64}$

This bird's eye view of increasing credit to supply higher demand confirms both good market conditions in Mexico and an effective management of the funds on the part of Misericordia guardians, whose connections and networks with Mexican trading families and companies cannot be underestimated, starting in the 1720s and especially in the 1730s and the 1740s. A bullish market would encourage more donors to entrust their gifts to the Misericordia. Conversely, tougher markets and sufficient credit supply from other sources led to the slowdown of foundations after the 1750s. Trade with Mexico always remained

61. Provisor Manuel Antonio de Ocio y Ocampo to king, July 5, 1728, Manila. AGI, Filipinas, 234.

62. AGI, Filipinas, 595, 865; NAP, SDS, 19165.

63. AGI, Filipinas, 595, 865; NAP, SDS, 19165. In the 1750s, loans for the Asian trade, mostly with China, did not exceed 20,000 pesos. Between 1764 and 1787, the average money lent for trade with China, Java, and Coromandel was 45,000 pesos yearly, and between 1788 and 1821, the average given for the same destinations was 26,000 pesos.

64. Hoberman, Mexico's Merchant, 214-220. Yuste in Emporios transpacificos makes frequent references to the habitual practice of introducing unreported merchandise in excess of the allowed limit, as well as to the equally frequent practice of Mexico City merchants' consignments of silver to their commercial relations in Manila as advance payment for merchandise. See for example Yuste, Emporios transpacificos, 316-337; and Bonialian, El Pacifico hispanoamericano, 217-226. 
high, but after the middle of the century it was increasingly disturbed by a series of difficulties: war with Britain; relatively lower demand in Mexico; removal of the Acapulco port officer Juan Eusebio Castellano, who had allowed the Mexican cartel to engage in the trade since the 1720s; and greater royal pressure to avoid such involvement. Further problems came from the mercantilist legislation of the Spanish government, specifically, the gradual opening of Spanish ports to foreign vessels and the privileges given to the Compañía de Filipinas to travel directly to Asian ports and bring goods to Manila free of tariffs, both of which slowly eroded the monopoly status of the galleon. ${ }^{65}$ From the 1780s onward, galleons were not able to leave yearly for Acapulco.

The presence of traders with strong ties to large commercial houses from Mexico City in the confraternity was far from disinterested. Early on, confraternity members were excluded from borrowing, as the statutes declared, but they favored relatives, partners, and relations. Many borrowers, like Francisco Carriedo y Perea and Juan Pablo Orduña, would become members in later years. But by the 1750s, members of the Misericordia themselves borrowed respondentia loans, forming trading networks of borrowers and guarantors. ${ }^{66}$ It is little wonder that these webs of merchants remained in the management of the confraternity until the end of commerce with Mexico. Prioritizing borrowers who offered more security or had better records, like relatives or other relations, was also common in Church corporations administering pious works in Spanish America. ${ }^{67}$

Incidentally, a recurrence in the history of the legacies confirms the strong link between the merchant classes in Manila and Mexico and the mutual interest in keeping the funds. Every time there was a near-collapse of respondentia loans, some old debts were honored in Mexico and a small influx of funds revived the credit. This happened after the 1690s, but it was especially relevant after the British confiscated all the funds of the Misericordia and the other Obras Pías during their occupation of Manila in the 1760s. Finally, even after Mexico became independent from Spain in 1821, Mexican traders honored their debts and Manila merchants paid the capital and premiums of many of their loans. Thus, in 1823, the Misericordia received the last payment of respondentia loans

65. Josep M. Fradera, Filipinas, la colonial más peculiar. La hacienda pública en la definición de la politica colonial, 1762-1868 (Madrid: Consejo Superior de Investigaciones Científicas, 1999), 90-93; Yuste, El comercio de la Nueva España, 31-40; Yuste, Emporios transpacificos, 359-381; Yuste, "Las familias de comerciantes," 65-66.

66. Fr. Manuel Antonio de Ocio y Ocampo to king, July 5, 1728, AGI, Filipinas, 234; Testimony of the notaries public pertaining to the contracts of obras pías in the Sacra Familia galleon; September 25, 1722, AHN, Clero, Jesuitas, 93; loans in the El Pilar galleon, 1750, NAP, SDS, 19165, fols. 93r-100v; Reports of Francisco Enríquez de Villacorta on the accounts of the Misericordia, July 6, 1752 and July 18, 1753, AGI, Filipinas, 569; and Report of Juan Antonio Panelo, May 8, 1754, NAP, SDS, 19165, fols. 459r-497r.

67. Burns, Colonial Habits, 139, 146-152. 
from Mexican markets, amounting to the large sum of 793,862 pesos. ${ }^{68}$ As trade with Mexico was discontinued, this payment is especially relevant, for it shows a good relationship between the merchants on both sides of the ocean, and is especially indicative of how both parties respected the sacred character and purpose of those funds.

\section{CHARITY FundRAISING}

The background of the donors, the way the legacies were created, and the purpose given to the earnings confirm the philanthropic character of the respondentia endowments in Manila. This is not incompatible with the involvement of Mexican trading cartels in the Obras Pías of Manila, whose presence in turn also benefitted commercially the progress of the charitable funds. Like any other endowment, these bequests naturally favored the creation of capital and the preservation of the trust fund. But when compared to other long-term fundraising endowments, both in the past and in the present, the strategy and the results were better. The respondentia endowments managed by the Misericordia allocated a high percentage of the investment's fixed capital to charity, between 17 and 25 percent-much higher than the fixed 5 percent garnered from pious works based on liens. Thus, Friar San Román fixed the percentage of charity from Saravia's endowment at a little less than 17 percent of its capital, which was equivalent to 12,500 pesos of almsgiving yearly. Bishop González's legacy of 80,200 pesos contemplated giving 18,000 pesos yearly, or 22 percent of its final capital, to charity. Otero Bermúdez wanted his bequest to reach a stable capital of 12,000 and earmarked 2,100 pesos for charities from the earnings of the yearly loans of one-third of the capital, which was equivalent to 18 percent. There are some telling exceptions, but the percentages are still high. Basarte in 1703 and De la Vega in 1734 left only 12.5 percent for charity from a seed capital of 50,000 pesos, while Carriedo allotted only 13.5 percent. The most conspicuous was Echeveste, whose target capital was of 100,000 pesos, while the amount he assigned to charity was only 2,500 pesos yearly.

The documentation shows that the guardians of the Misericordia respected the legacies' sacred character and distributed earnings according to their donors' stipulations. Nevertheless, the vicissitudes of transpacific trade in this period seriously affected the legacies' charitable function. In the early years of the bequests, the still small amounts given to beneficiaries came to a halt with the galleon mishaps of 1692-94 and 1705. Thus, in 1708 the Misericordia was 
able to disburse only 400 pesos to the Colegio de Santa Isabel and the church of the confraternity. ${ }^{69}$ As the capital recovered, certain beneficiaries began receiving yearly gifts (starting in 1719), depending on the conditions set by the founder and the loans' profitability. This period of stability in charitable donations lasted until $1742 .^{70}$

A document that details the distribution of earnings from respondentia endowments for the year 1741 exists in the archives. The long list of beneficiaries encompasses practically all of Manila's ecclesiastical entities and their charities. Various types of destitute persons also received alms. Charitable donations reached the astronomic figure of 67,080 pesos, and this was well below the 100,000 plus pesos that would have been available for donation if the legacies' growth had not experienced any delays. Comparing the percentages of donations prescribed by the endowments' founders with the percentages of the actual allocations proves that Misericordia guardians generally followed donors' wishes. Nevertheless, in some cases, such as in 1741, the mesa used funds at a level of capital that contravened the donor's stipulations, demonstrating that guardians exercised a good deal of discretion favoring projects or expenses that they handled directly, such as the Colegio de Santa Isabel and the administration of the facilities of the confraternity and other preferred charities. $^{71}$

Another period of instability ensued during the years after the British capture of the Covadonga galleon in 1743, during which capital sums decreased and distribution of donations ceased. The situation was aggravated because the Misericordia had used capital reserves to renew the facilities of its own offices. Financial recovery was rather slow, with the distribution of small disbursements beginning in 1748, and the number of beneficiaries slowly increasing until 1760, when almost everyone had a share. ${ }^{72}$ The British occupation of Manila between 1762 and 1764 brought another crisis. In the last quarter of the eighteenth century, the difficulties of transpacific trade described above logically affected the disbursement of charitable handouts. Yearly average donations from the Misericordia's legacies between 1774 and 1823 varied between the

69. Relación de las obras pías que administra la mesa de la Santa Misericordia de la ciudad de Manila, June 5, 1708, Manila, AGI, Filipinas, 290.

70. Minutes of the special junta of the Misericordia confraternity, January 11, 1723, Manila, Archivo de la Provincia del Santo Rosario (APSR), Manila, Microfilm 109; Colegio de Santo Tomás, Obra pía del Señor Don Andrés para el Colegio que administra la mesa de la Misericordia; AUST, Becerros, Tomo 22; Manchado, "Las controversias en torno," 435 .

71. Minutes of the mesa, October 11, 1741, Manila, NAP, SDS, 19165, fols. 185v-201v.

72. Royal Decree, November 8, 1747, San Lorenzo, NAP, SDS, 19165, fols. 2r-15r; Mesa meeting, November 20, 1750, Manila, NAP, SDS, 19165, fols. 24r-53v; Mesa to Visitador Francisco Enríquez de Villacorta, June 7 , 1756, Manila, NAP, SDS, 19165, fols. 648r-650v; Colegio de Santo Tomás, obra pía del Señor Don Andrés para el Colegio que administra la mesa de la Misericordia, AUST, Becerros, Tomo 22. 
4,260 pesos for the period from 1799 to 1803 , when the Misericordia was forced to donate money to the government to reinforce Manila's fortifications, and the 24,876 pesos of the last five years of the trade. ${ }^{73}$ The money distributed may have been much less than what was ideally stipulated for each beneficiary, but the beneficiaries, who were aware of the intricacies of this type of legacies, appreciated the donations.

Despite the efforts of the Misericordia mesa to implement donors' wishes, a blatant exception was its consistently preferential treatment of the Colegio de Santa Isabel. In times of crisis, it was the first or even the only recipient of funds. And in 1798, some 130 years after the founding of the first legacy, the guardians unlawfully increased the administration fee charged by the confraternity for the legacies. Moreover, the ecclesiastical judge of the dioceses, a former proveedor, approved the transfer to the Colegio de Santa Isabel of the interest from legacies worth 100,000 pesos that were earmarked for other beneficiaries. $^{74}$

\section{CONCLUSION}

Can respondentia legacies of the Misericordia, and the other Obras Pías, be considered a ruse of Mexican traders to continue providing capital for their commercial ventures in Manila? The study of the various legacies seems to point otherwise. Of the 59 endowments, 29 were testamentary legacies, and were therefore of little commercial self-interest to the donors, so that it would be reasonable to attribute a religious or philanthropic motive. The salvation of one's soul was no mean feat. Nine clergymen set up legacies simply to generate funds for projects they wanted to finance. Most of the donors were Manila-based, had considerable personal wealth, and would not gain much by favoring an influx of Mexican capital. Therefore, it is safe to maintain that their primary charitable intent is unquestionable. Besides, establishing a pious endowment could bring other intangible gains, like the social prestige attached to having a charity in perpetuity under one's name. Another marginal reason to part with one's capital as a legacy could have been the desire for the city and the colony to prosper, inspired by a sense of social responsibility, given the

73. Mesa de la Misericordia, Financial Statements, 1774 to 1823, AGI, Filipinas, 595; Reports of Comisión Liquidadora de las Cuentas de la Real Casa de la Misericordia, March 30 and September 12, 1871, Manila, NAP, SDS, 19075 , fols. 142r-148r, 190r-210r.

74. Estado individual por quinquenio de las cantidades de peso que se han introducido en el Tesoro de la Hermandad de la Misericordia de la ciudad de Manila en los años de 1750, 1751, 1752, 1753, y 1754, así por vía de legado e lo pertinente a las obras de censos, y cinco por ciento de Administración en las de correspondencia, como por razones de préstamo . . . , March 12, 1756, Manila, NAP, SDS, 19075, 248r-257r; NAP, SDS, 19182, 787r-789r, 276r-285r; AAM, 9.A.1, Obras Pias (1615-1919), Folder 11. 
archipelago's crucial dependence on transpacific commerce. Perhaps there would even be the consideration that commercial associates could also benefit from the funds. Martínez Castellanos had a truly brilliant idea when he decided to set up the first respondentia endowment under the care of the Misericordia. He revived pious gift-giving in Manila and, most likely unwittingly, planted the seed for the creation of virtual commercial banks in the city.

This study confirms the involvement of the commercial houses of Mexico in the Obras Pías of Manila, especially after 1722. However, the findings on the founders of the legacies invert the suggested argument, demonstrating that it was not so much that Mexicans created the endowments, but rather that the endowments, among other factors, attracted the Mexicans to move to Manila and to join the Misericordia and other Obras Pías. For those with stable commercial networks in America, having another credit source to buy Chinese products was a welcome incentive to migrate. Once in Manila, these traders lost no time in getting involved in the government of the Obras Pías, where they could favor their commercial networks. In turn, they channeled their pious largesse to create new endowments with which to sponsor some charity, gain spiritual benefits, and contribute to the pool of credit in Manila. Riding on the upward trend of the galleon trade and the new gifts, the Obras Pías' capital kept growing to supply the high demand with larger capital for lending, especially as the permitted trading load was increased. They thereby made available and promoted a credit instrument that this generation of merchants did not invent, but one that worked for their benefit. It is also remarkable that the creation of new legacies tapered off as the demand for merchandise plateaued, due to more checks on Mexican money in Acapulco and changes in international trading conditions.

Martínez Castellanos's recourse to respondentia endowments was a very innovative and promising approach to philanthropy at a time when lien-based legacies had lost appeal, and it provided an alternate framework through which Manila's citizens could channel their charity. ${ }^{75} \mathrm{Had}$ the respondentias operated as planned, many of the financial problems of religious institutions and the relief of the city poor would have been satisfactorily addressed. However, just as it occurred with the lien-based legacies in Manila and elsewhere in Spanish America, environmental and historical causation disrupted the ideal flow of things. Documentation proves that the guardians of the Misericordia were conscious of the sacredness of the endowments and their religious commitment to abide by the statutes of the confraternity, which constrained them to distribute the earnings among the rightful beneficiaries. The only exception in

75. Schwaller, Origins of Church Wealth, 140. 
this regard was the privileged status granted to the Colegio de Santa Isabel, an irregularity that they seemed to contemplate as positive, since by caring for and educating Spanish and mestizo girls, they were providing a direct service to the community, which needed future wives and mothers to secure and develop the colony. If we compare the benefits that respondentia endowments generated for commercial credit with those generated for charity in Manila, the balance would clearly tilt on the side of the first. ${ }^{76}$ Nevertheless, although it is in the nature of endowments to have a large imbalance between capital and interest, the imbalance in this kind of bequest was smaller than it was in lien-based investments.

In summary, respondentia legacies fulfilled multiple functions in this small Spanish city in Asia. Likewise, membership in the Misericordia entailed a combination of service and benefits, as can be learned from a lawyer's advice to the mesa of 1758, which was at the time deliberating whether to borrow money from the endowments to pay for some repairs in the Colegio de Santa Isabel:

There are brothers in the institution with enough fortune to supply [the brotherhood] in the present emergency, and I do not doubt that they will gratefully want to provide the donation needed to avoid the destruction and extinction of such a work . . . because aside from the merit they earn, they [also] somehow repay the benefits they have obtained, which may well be that of having obtained their fortune with the help of this institution. ${ }^{77}$

University of Asia and the Pacific, Manila

JUAN O. MESQUIDA

The Philippines

juan.mesquida@uap.asia

76. Isabel dos Guimarães Sá, "As Misericórdias nas sociedades portuguesas do período moderno," Cuadernos do Noroeste, 15:1-2 (2001): 350. Sá has found similar or even greater imbalances between the amounts set for loans and the money devoted for charity in the Misericordia of Macao during the third quarter of the eighteenth century.

77. Reports on the repairs of the Colegio de Santa Isabel and the source of funds needed, with the opinions of theologians and lawyers, April 26-June 20, 1758, Manila, NAP, SDS, 19076, fols. 1r-26v. 


\section{AnNex}

TABLE A

Respondentia Endowments of the Misericordia Confraternity (1668-1810)

\begin{tabular}{|c|c|c|c|c|c|c|}
\hline & Founder & Social Status & Executor & $\begin{array}{l}\text { Foundation } \\
\text { Date }\end{array}$ & $\begin{array}{l}\text { Original } \\
\text { Amount }\end{array}$ & $\begin{array}{l}\text { Final } \\
\text { Principal }\end{array}$ \\
\hline 1 & Martínez Castellanos, Diego & Captain & Gómez de Aráujo, Juan & $1668-1669$ & 3,927 & 4,000 \\
\hline 2 & García de Cárdenas, Tomás & General, city councilor & - & 1675 & 12,000 & 12,000 \\
\hline 3 & León y Saravia, Manuel de & Governor of the Philippines & $\begin{array}{l}\text { San Román, O.P., Fr. Diego } \\
\text { de }\end{array}$ & $1677-1680$ & 50,000 & 75,000 \\
\hline 4 & $\begin{array}{l}\text { Cabildo, Regimiento y } \\
\text { Vecindario (city council) } \\
\text { Title: Del común de la } \\
\text { república }\end{array}$ & - & - & 1694 & 446 & 1,200 \\
\hline 5 & $\begin{array}{l}\text { Oponte y Andrade, Alonso } \\
\text { de }\end{array}$ & Field Marshall, city councilor & Quintero, Marcos & $1694-1697$ & 8,000 & 8,000 \\
\hline 6 & Vázquez y Urias, José & - & Quintero, Marcos & $1694-1697$ & 4,000 & 4,000 \\
\hline 7 & Quintero, Marcos & General, city councilor & - & 1698 & 4,000 & 4,000 \\
\hline 8 & Endaya, Tomás de & Field Marshall, city councilor & - & 1699 & 8,000 & 8,000 \\
\hline 9 & Urquiza, Lucas Mateo de & General & $\begin{array}{l}\text { Oliva, Captain Sebastián de } \\
\text { la }\end{array}$ & 1700 & 2,000 & 2,000 \\
\hline 10 & González, Andrés & Bishop of Nueva Cáceres & - & 1701 & 25,500 & 80,200 \\
\hline 11 & Basarte, Antonio & Sargento Mayor, city councilor & Mesa de la Misericordia & 1703 & 9,849 & 50,000 \\
\hline 12 & Ferrer, Felipe & - & Mesa de la Misericordia & 1703 & 4,000 & 4,000 \\
\hline 13 & Sidoti, Juan Bautista & Prelate, Pope's envoy to China & - & 1705 & 21,000 & 40,800 \\
\hline 14 & Vega Carballo, Nicolás de la & Doctor & Rayo Doria, Dr. Francisco & $1712-1721$ & 500 & 500 \\
\hline 15 & Escaño y Córdova, María (1) & Widow; galleon trader & $\begin{array}{l}\text { Otero Bermúdez, General } \\
\text { Domingo Antonio de } \\
\text { (her son-in- law) }\end{array}$ & 1713 & 1,002 & 1,000 \\
\hline
\end{tabular}


Table A Continued.

\begin{tabular}{|c|c|c|c|c|c|c|}
\hline & Founder & Social Status & Executor & $\begin{array}{l}\text { Foundation } \\
\text { Date }\end{array}$ & $\begin{array}{l}\text { Original } \\
\text { Amount }\end{array}$ & $\begin{array}{l}\text { Final } \\
\text { Principal }\end{array}$ \\
\hline 16 & $\begin{array}{l}\text { Brothers of the Misericordia } \\
\text { Title: Nueva Congregación } \\
\text { de Nuestra Señora de la } \\
\text { Presentación }\end{array}$ & - & - & 1718 & 700 & 6,000 \\
\hline 17 & $\begin{array}{l}\text { Purificación, Fr. Pedro de la } \\
\text { Title: Nuestra Señora de la } \\
\text { Salud }\end{array}$ & $\begin{array}{l}\text { Prior of the Convent of San } \\
\text { Juan de Bagumbaya, } \\
\text { Recollect }\end{array}$ & - & 1718 & 600 & 600 \\
\hline 18 & $\begin{array}{l}\text { Cuesta, Francisco de la } \\
\text { Title: Nuestra Señora de Guía }\end{array}$ & Archbishop of Manila & - & 1718 & 2,500 & 3,750 \\
\hline 19 & $\begin{array}{l}\text { Virdis, Fr. José, S.J. } \\
\text { Title: Indios de las Marianas }\end{array}$ & Procurator of the Jesuits & - & 1721 & 2,000 & 2,000 \\
\hline 20 & Hernández Delgado, Tomás & Captain & $\begin{array}{l}\text { Cortés de Arredondo, } \\
\text { Captain Juan Antonio }\end{array}$ & 1722 & 1,000 & 1,500 \\
\hline 21 & Angulo, Fernando de & General & $1+$ & 1724 & 2,000 & 6,000 \\
\hline 22 & Escaño y Córdova, Maria (2) & & $\begin{array}{l}\text { Otero Bermúdez, General } \\
\text { Domingo Antonio de }\end{array}$ & 1724 & 1,000 & 1,000 \\
\hline 23 & Martínez Lobo, Manuel (1) & Captain, Portuguese & Mesa de la Misericordia & 1727 & 3,300 & 12,000 \\
\hline 24 & Martínez Lobo, Manuel (2) & & Mesa de la Misericordia & 1727 & 600 & 12,000 \\
\hline 25 & Morales, José (1) & General & - & 1727 & 600 & 3,000 \\
\hline 26 & Amechesurra, Simón de & $\begin{array}{l}\text { Administrator of the Hospital } \\
\text { de San Lázaro }\end{array}$ & - & 1728 & 2,000 & 9,000 \\
\hline 27 & $\begin{array}{l}\text { Otero Bermúdez, Domingo } \\
\text { Antonio de }\end{array}$ & $\begin{array}{l}\text { General, city councilor, } \\
\text { Merchant }\end{array}$ & - & 1729 & 3,000 & 12,000 \\
\hline
\end{tabular}



28 Beltrán de Salazar, José $\quad$ Sargento Mayor, city councilor
Title: Santo Cristo del Tesoro

29 Morales, José (2)

30 Fuentes, Ambrosio

Treasurer of the Cathedral

31 Otero Bermúdez, Domingo General, city councilor Antonio de

Title: San Andrés

33 Collantes Peredo y Trillanes, Widow María Joaquina

34 Andrade y Villapol, Gaspar Sargento Mayor Carlos de

35 González del Rivero y General, Marquis of Quijano, Pedro (1)

36 Vibanco, Franciso

Montecastro y

Llanahermosa
32 Vega, Pedro Basilio de la $\begin{array}{ll}\qquad- & 1731 \\ \begin{array}{l}\text { Fuente Yepes, Chantre Juan } \\ \text { de la }\end{array} & 1731\end{array}$

Fuente Yepes, Chantre Juan 1732 de la

1733

Andrade y Villapol,

Sargento Mayor Carlos

de

Otero Bermúdez, General

Domingo Antonio de

Gómez de Bustamante,

General Manuel

1734

1736

1739

-

1739

Captain, married to the cousin Céspedes, Manuel de of the Marquis of

Montecastro y

Llanahermosa

37 Pérez de Tagle, Juan Manuel Sargento Mayor, Marquis of Las Salinas, Field Marshall of

Cavite port

Second Lieutenant

Pérez de Tagle, Juan

1740

Manuel

González del Rivero, Pedro 1743

Domingo
$1,600 \quad 12,000$

$6,600 \quad 30,000$

$4,000 \quad 12,000$

$1,000 \quad 3,000$

$4,000 \quad 50,000$

$4,000 \quad 12,000$

$8,000 \quad 24,000$

$5,772 \quad 36,000$

$1,000 \quad 3,000$

$4,000 \quad 12,000$

$1,446 \quad 12,000$

$4,000 \quad 6,000$

$6,000 \quad$ w

(Contimued) oิ 
Table A Continued.

\begin{tabular}{|c|c|c|c|c|c|c|}
\hline & Founder & Social Status & Executor & $\begin{array}{l}\text { Foundation } \\
\text { Date }\end{array}$ & $\begin{array}{l}\text { Original } \\
\text { Amount }\end{array}$ & $\begin{array}{l}\text { Final } \\
\text { Principal }\end{array}$ \\
\hline 40 & $\begin{array}{l}\text { Gómez de Bustamante, } \\
\text { Manuel }\end{array}$ & General & Sons and son-in- law & 1744 & 2,000 & 6,000 \\
\hline 41 & $\begin{array}{l}\text { Maldonado de Puga, Fr. } \\
\text { Manuel } \\
\text { Title: Nuestra Señora de los } \\
\text { Gozos y Señor San Juan de } \\
\text { Dios }\end{array}$ & $\begin{array}{l}\text { Head chaplain, Hospital de San } \\
\text { Juan de Dios }\end{array}$ & - & 1745 & 8,600 & 15,000 \\
\hline 42 & $\begin{array}{l}\text { Pérez de la Fuente, Teresa } \\
\text { Title: San Ignacio de Loyola y } \\
\text { San Francisco Xavier }\end{array}$ & Widow & $\begin{array}{l}\text { Fernández Toribio, } \\
\text { Licenciado Francisco }\end{array}$ & 1745 & 2,227 & 12,000 \\
\hline 43 & $\begin{array}{l}\text { Carriedo y Peredo, Francisco } \\
\text { (1) }\end{array}$ & General & $\begin{array}{l}\text { Marquis of Montecastro y } \\
\text { Llanahermosa }\end{array}$ & 1748 & 8,000 & 36,000 \\
\hline 44 & $\begin{array}{l}\text { Carriedo y Peredo, Francisco } \\
\text { (2) }\end{array}$ & & $\begin{array}{l}\text { Marquis of Montecastro y } \\
\text { Llanahermosa }\end{array}$ & 1748 & 8,000 & 36,000 \\
\hline 45 & $\begin{array}{l}\text { Torre y Ayala, Gaspar de la } \\
\text { Title: Nuestra Señora de } \\
\text { Belén }\end{array}$ & Governor of the Philippines & $\begin{array}{l}\text { Monterrosso, General Juan } \\
\text { Ignacio de }\end{array}$ & 1748 & 6,000 & 18,000 \\
\hline 46 & Arrechederra, Fr. Juan de & Bishop of Nueva Segovia & - & 1749 & 4,000 & 6,000 \\
\hline 47 & $\begin{array}{l}\text { Brotherhood of the } \\
\text { Misericordia } \\
\text { Title: Del Desempeño }\end{array}$ & - & - & 1749 & 13,500 & 24,000 \\
\hline 48 & Fuente Yepes, Gregorio de la & Maestro (priest) & $\begin{array}{l}\text { Fuente Yepes, Dean Juan de } \\
\text { la }\end{array}$ & 1754 & 6,159 & 21,000 \\
\hline 49 & Reoyo, Lorenzo & & $\begin{array}{l}\text { Fuente Yepes, Dean Juan de } \\
\text { la }\end{array}$ & 1754 & 7,012 & 21,000 \\
\hline
\end{tabular}


50 Echeveste, Francisco de

51 Novia, Lorenzo

Title: Nuestra Señora

de Begoña

52 Iriarte, Felipe

53 Creditors of Matías Suárez

54 Urilla, Juan Simón de

55 Platé, Luis

56 Ceraín, Felipe de (1)

57 Lara, Manuela de

58 Ceraín, Felipe de (2)

59 Ceraín, Felipe de (3)
General, city councilor, residing in Mexico City

Count of Lizárraga

Residing in Mexico City

Marshall of

Colonel, Field Mars

Cavite Port

Widow of Diego García

Herreros
Andano, Manuel de;

Meabe, Ambrosio and

Echeveste, Juan José

768

$1778 \quad 21,124 \quad 30,000$

$\begin{array}{lll}1784 & 21,798 & 108,780\end{array}$

$1,800 \quad 1,000$

$1805 \quad 16,000 \quad 16,000$

$1808 \quad 30,000 \quad 30,000$

Díaz Durana, Francisco, $1808 \quad 30,000 \quad 30,000$
Canon

\section{Canon}

1809

1,500

1,500

Díaz Durana, Francisco,

1810

30,261

30,261

Canon

Díaz Durana, Francisco,

1810

28,561

28,561

Sources: Cuenta en cargo y data que presentaron el Proveedor y diputados de la Hermandad y Casa Real de la Santa Misericordia, de la ciudad de Manila, al Señor Licenciado D. Francisco Enríquez de Villacorta . . . desde 22 de noviembre de 1754 . . . a 22 de noviembre de 1755, . .., NAP, SDS, 19165; Estado general y circunstanciado de las obras que se hallan bajo la Administración de la Real Casa de la Santa Misericordia, n. d., Archdiocesan Archives of Manila, 9, A.l., Obras Pías (1615-1919), folder 2C; Obras pías. Sus Fundaciones, NAP, SDS, Obras Pías, Bundle I, 242r-25lv; Mesa de la Misericordia, Financial Statements, 1804 to 1823, AGI, Filipinas, 595; and Joaquín Colomo to governor, January 22, 1878, Manila, NAP, SDS 19182, 405r-406r. 